\title{
The Application of Low-Valent Titanium Reagents in Organic Synthesis
}

\author{
Dieter Lenoir \\ Lehrstuhl für Ökologische Chemie und Geochemie der Universität Bayreuth, Postfach 101251, D-8580 Bayreuth, Federal Republic of Germany \\ The number and variety of applications of low-valent titaniun reagents \\ has expanded greatly since their initial use in 1973. This review exami- \\ nes the preparation of low-valent titanium reagents and their develop- \\ ment as reagents for inter- and intramolecular coupling, reductive \\ elimimation and alkylidenation, with reference to aspects of the mecha- \\ nism and stereoselectivity. \\ 1. Introduction \\ 2. Low-Valent Titanium Reagents \\ 2.1. Preparation \\ 2.2. Mechanism and Stereoselectivity \\ 3. Intermolecular Coupling of Aldehydes and Ketones \\ 3.1. Preparation of Alkenes \\ 3.1.1. Preparation of Strained Ethylenes \\ 3.1.2. Preparation of Aromatic Olefins \\ 3.1.3. Mixed Coupling of Carbonyl Groups \\ 3.1.4. Scope and Limitation of the Coupling Reaction \\ 3.1.5. Selective Coupling of Ketones and Aldehydes \\ 3.1.5.1. Groups with Large Reduction Potentials \\ 3.1.5.2. Groups with Low Reduction Potentials \\ 3.2. Preparation of Glycols \\ 3.2.1. Mixed Coupling of Carboryl Compounds \\ 4. Intramolecular Couplings of Carbonyl Groups \\ 4.1. Preparation of Cycloalkenes and Cyclic Ketones \\ 4.2. Preparation of Cyclic Diols \\ 5. Reductive Eliminations \\ 5.1. Deoxygenation of Glycols \\ 5.2. Reductive Eliminations of Other Groups \\ 6. Alkylidenation of Carbonyl Groups \\ 6.1. Methylenations \\ 6.2. Alkylidenations \\ 7. Conclusions and Summary
}

\section{Introduction}

The reductive coupling of aldehydes and ketones to give alkenes by low-valent titanium species, generated in situ, was first reported independently between 1973 and 1974 by Tyrlik et al., Mukaiyama et al., ${ }^{2}$ and McMurry et al. ${ }^{3}$ The latter used titanium trichloride and lithium aluminum hydride to generate the low-valent titanium species; this has been further elaborated by McMurry and co-workers, ${ }^{4,5}$ and is now generally referred to as, "the McMurry reaction". The reaction conditions have also been moditied, for instance titanium tetrachloride / zinc has been developed as a reagent and is now widely used. ${ }^{2.6}$ The reaction has also been reviewed, the applications of the reaction were covered some years ago. ${ }^{5.7 .8 .9} \mathrm{~A}$ detailed study of the mechanism of the reaction has also been published by (seise and co-workers. ${ }^{10}$

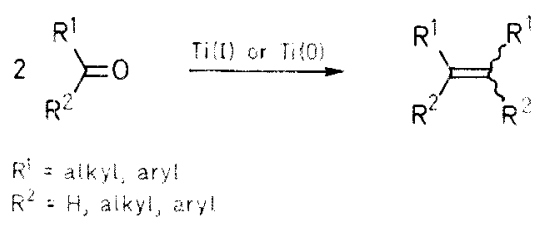

After a short introduction into the mechanistic aspects, the scope and applications of low-valent titanium species in synthetic organic chemistry will be covered in depth. Recent advances in the alkylidenation of carbonyl compounds using titanium carbene complexes will also be discussed.

\section{Low-Valent Titanium Reagents}

\subsection{Preparation}

The yield and stereoselectivity of low-valent titanium coupling reactions are dependent upon; the choice of titanium reagent, its preparation, and the applied experimental conditions. ${ }^{10}$ The reagents and solvents must be pure and absolutely dry, since traces of oxidation and hydrolysis products can interfere with the reaction and reduce the yield. The reaction should therefore be performed under a dry argon atmosphere.

A $\operatorname{Ti}(0)$ or a $\operatorname{Ti}(\mathrm{I})$ species can be prepared depending on the reducing conditions applied. ${ }^{10}$ Titanium trichloride is reduced by lithium aluminum hydride ${ }^{4,5}$ according to the stoichiometric equation:

$5 \mathrm{TiCl}_{3}+3 \mathrm{LiAlH}_{4} \rightarrow 5 \mathrm{Ti}(0)+3 \mathrm{Al}(0)+12 \mathrm{HCl}+3 \mathrm{LiCl}$

The following reducing agents have also been applied to titanium trichloride; lithium. ${ }^{10.11}$ sodium, ${ }^{10}$ potassium. ${ }^{4+10}$ potassium-graphite intercalate $\left(\mathrm{C}_{8} \mathrm{~K}\right),{ }^{12}$ magnesium. ${ }^{1.10}$ zinc copper couple, ${ }^{13}$ and Rieke-titanium. ${ }^{14}$ It has been found that a slight excess of reducing agent is usually necessary to obtain an optimum yicld of the desired product. ${ }^{10}$ Titanium trichloride and lithium aluminum hydride can produce a $\mathrm{Ti}(0)$ or a $\mathrm{Ti}(\mathrm{l})$ species depending on the mole ratio of $\mathrm{TiCl}_{3} / \mathrm{LiAlH}_{4}$, a ratio of $1: 0.6$ produces a Ti(0) species and $1: 0.5$ a $\mathrm{Ti}(\mathrm{I})$ species. Both of these reagents are commercially available.

Starting from titanium tetruchloride, the reduction to low-valent titanium can be performed by zinc, ${ }^{2.6}$ zinc-copper couple, ${ }^{15}$ magnesium/mercury, ${ }^{16}$ aluminum/aluminum trichloride. ${ }^{16}$ or 


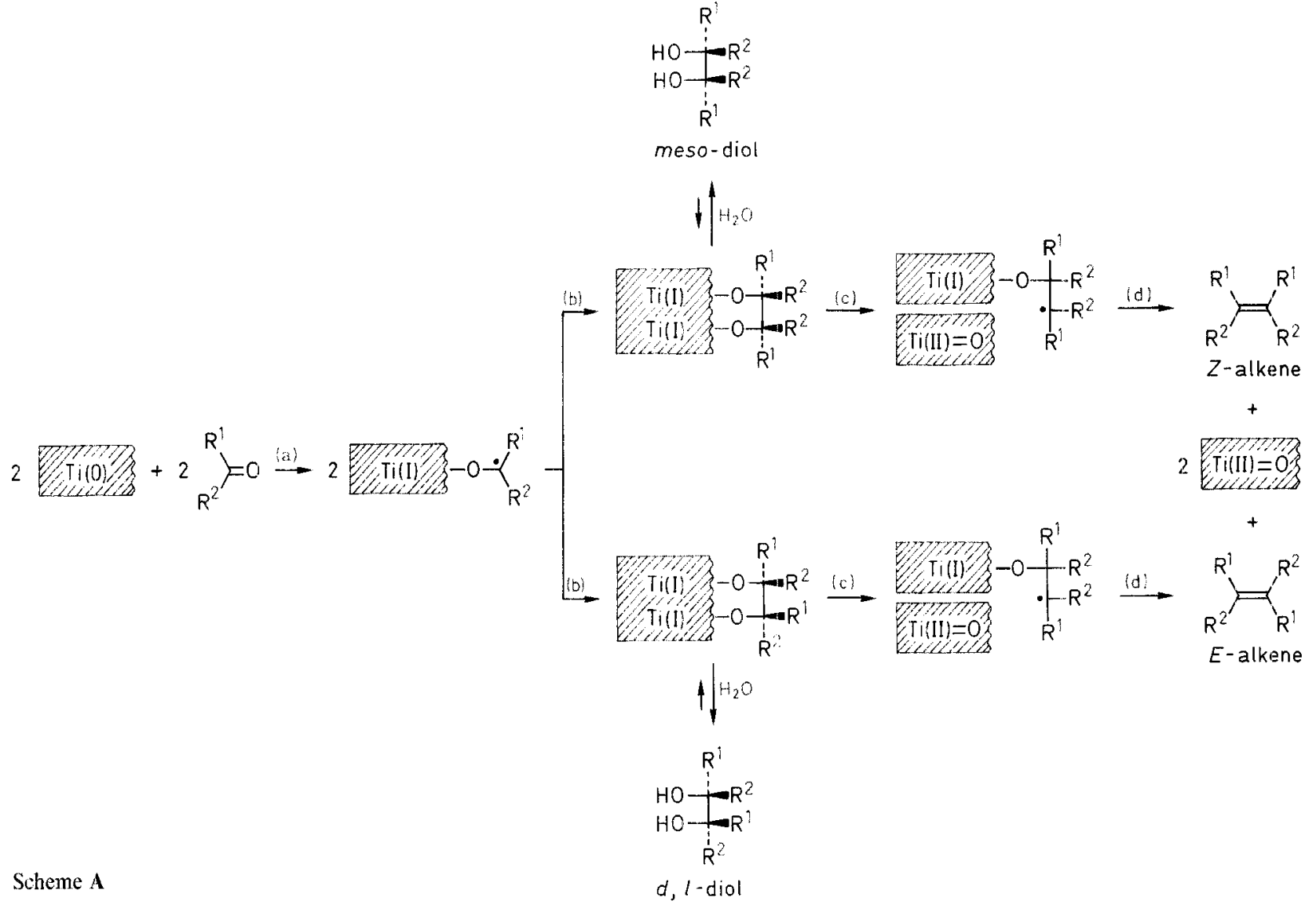

lithium aluminum hydride. ${ }^{17}$ Dicyclopentadienyltitanium dichloride and trimethylaluminum, ${ }^{16,18}$ or with Grignard reagents, ${ }^{19}$ has also been used.

Tetrahydrofuran is usually the solvent of choice for the reaction but dioxane and dimethoxyethane are also applied. The reaction conditions have also been carefully elaborated to obtain optimum yields by the preparation of a crystalline titanium trichloride dimethoxyethane complex which is reduced by zinc-copper couple. ${ }^{20}$

\subsection{Mechanism and Stereoselectivity}

A black slurry of low-valent titanium species is freshly prepared, the carbonyl compound is added and the reaction is allowed to proceed for a fixed time. The sequence of events is depicted mechanistically, both in solution and on the surface of the titanium, in Scheme A.

In the initial step (a), an electron is transferred from titanium to the carbonyl group generating a radical anion, which has been detected by ESR-spectroscopy. ${ }^{10}$ The ketyl radical then dimerizes to the corresponding pinacol (b), which can be isolated as the primary reaction product when low temperatures are used. Deoxygenation by a cis-type concerted mechanism of the pinacol occurs readily ( $c$ and $d$ ) leading to alkenes, due to the large affinity of titanium for oxygen. These reactions all occur on the surface of the titanium. 5,10

Stereoselectivity is observed in diol formation (ratio of meso to $d, l$-isomers) as well as in olefin formation (ratio of $E / Z$ isomers); these effects will be described below. The stereoselectivity of the olefin formation depends on the choice of the titanium reagent. ${ }^{6}$ The $E / Z$-ratio in coupling of aliphatic methyl alkyl ketones depends strongly on the steric bulk of the alkyl groups. $^{6}$

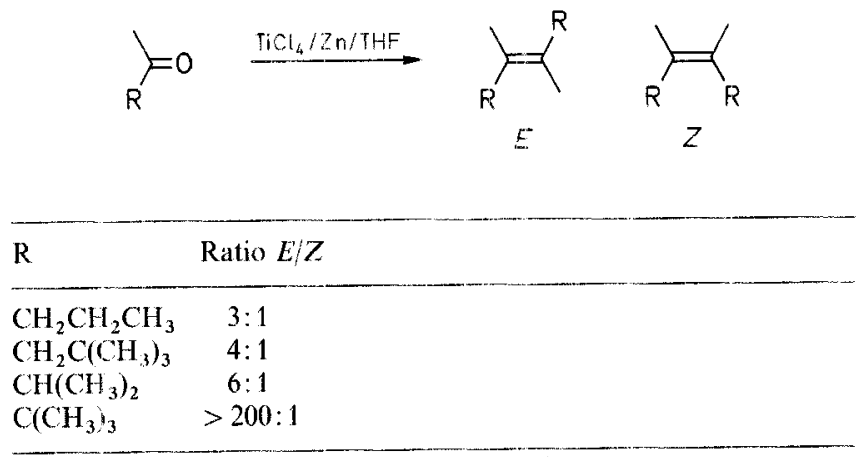

The observed $E / Z$ ratios are different when the low-valent titanium species is generated from $\mathrm{TiCl}_{3} / \mathrm{LiAlH}_{4}$; for example the ratio of $E / Z$ is close to unity in alkene formation from pinalone. The stereoselectivity of stilbene formation from benzaldehyde is also dependent on the reagents used to generate the titanium species. ${ }^{1,2,3}$

A complete rationale for these results has still to be found. The deoxygenation step also shows stereoselective behavior; mesoand $d, l$-isomers of the same glycols give different mixtures of $E / Z$ isomeric alkenes. ${ }^{4}$ More examples of this behavior will be given later.

\section{Intermolecular Coupling Aldehydes and Ketones}

\subsection{Preparation of Alkenes}

Low-valent titanium reagents have been widely used for the preparation of symmetrical alkenes, starting from the corresponding aldehyde or ketone. There are many examples, for a selection refer to previous reviews. 5,7,8,9 
Some synthetically useful examples will be discussed in this section. $\beta$-Carotene (2), a food coloring compound and precursor of vitamin A, can be prepared in high yield from retinal (1). The titanium reagent for the coupling can either be $\mathrm{TiCl}_{3}$ $\mathrm{LiAlH}_{4},{ }^{3}$ or $\mathrm{TiCl}_{4} / \mathrm{LiAlH}_{4}$ in the presence of a proton sponge. ${ }^{17}$ Dimestrole (4), precursor of diethylstilbestrol, can be prepared from the ketone $3 .^{4}$<smiles>C/C=C/C=C(C)\C=C\C=C(C)\C=C\C1=C(C)CCCC1(C)C</smiles>

1<smiles>CC1=C(/C=C/C(C)=C/C=C/C(C)=C/C=C/C=C(C)/C=C/C=C(C)/C=C/C2=C(C)CCCC2(C)C)C(C)(C)CCC1</smiles>

2<smiles>CCC(=O)c1ccc(OC)cc1</smiles>

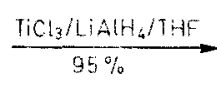

3

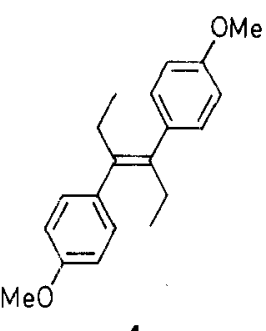

4

Worthy of note are the synthesis of mini-carotene, a lower homologue of $\beta$-carotene (2), ${ }^{21}$ and the $\mathrm{C}_{40}$-saturated terpenoid used as a crude oil marker. ${ }^{22}$

\section{Reductive Coupling of Aldehyde and Ketones; General Procedure}

Method $\mathrm{A}:{ }^{4} \mathrm{~K}$ metal $(1.92 \mathrm{~g}, 49 \mathrm{mmol})$ is washed with hexane to remove oil and is added to a stirred slurry of $\mathrm{TiCl}_{3}(2.15 \mathrm{~g}, 14 \mathrm{mmol})$ in dry THF $(75 \mathrm{~mL})$ at r.t. under an inert atmosphere. After refluxing for $40 \mathrm{~min}$, the black mixture is cooled and a solution of ketone or aldehyde $(3.5 \mathrm{mmol})$ in THF $(5 \mathrm{~mL})$ is added. After a further $16 \mathrm{~h}$ at reflux, the reaction mixture is cooled to r.t. and transferred by syringe to a glass filtration tube (medium frit) under an inert atmosphere. The mixture is vacuum filtered, and the filtrate is then concentrated by solvent removal on a rotary evaporator to yield the crude product. In this manner tetraisopropylethylene and 10-icosene are isolated by chromatography in $37 \%$ and $60 \%$ yield, respectively.

Method $\mathrm{B}:{ }^{6} \mathrm{Zn}$ dust $(10 \mathrm{~g}, 150 \mathrm{mg}$-atom) is added in small portions to $\mathrm{TiCl}_{4}(14.2 \mathrm{~g}, 8.2 \mathrm{~mL}, 75 \mathrm{mmol})$ in THF $(200 \mathrm{~mL})$ with ice cooling under an $\mathrm{N}_{2}$ atmosphere. Pyridine $(5 \mathrm{~mL})$ and ketone $(70 \mathrm{mmol})$ in THF $(200 \mathrm{~mL})$ are added. The mixture is heated at reflux for $20 \mathrm{~h}$. After being cooled to r.t., the reaction is quenched with $10 \%$ aq. $\mathrm{K}_{2} \mathrm{CO}_{3}$ $(150 \mathrm{~mL})$. The mixture is extracted with $\mathrm{Et}_{2} \mathrm{O}$ or pentane $(5 \times 50 \mathrm{~mL})$. The extract is washed with water twice, dried $\left(\mathrm{MgSO}_{4}\right)$, filtered, and concentrated under vacuum. The residue is isolated by chromatography on silica (Merck $60,0.2-0.6 \mathrm{~mm}, 60 \mathrm{~g}$ ) using pentane or hexane as an cluent. The alkene is obtained after evaporation of the solvent and further purified by standard procedures.

We have developed the latter procedure (Method B) and used it for the coupling of a wide variety of ketones. Although yields are sometimes a little lower compared to other procedures, the method is easy to perform and the reagents are less expensive. The addition of pyridine is not essential in most cases.

In general most monocyclic ketones of varying ring size, as well as polycyclic ketones, can be coupled to give the corresponding alkenes. The following alkenes have thus been obtained: cyclohexylidenecyclohexane (5a) ${ }^{4,20}$ and the alkyl derivative $5 \mathbf{b},{ }^{6}$ adamantylideneadamantane $(6)^{4}$ and the alkyl derivatives $6 \mathbf{b}, \mathbf{c}^{23}$ (4-protoadamantylidene)4-protoadamantane $7,6,24$ 4,4'-homoadamantylidenehomoadamantane (8), ${ }^{25}$ tetracyclopropylethylene (9) ${ }^{6}$ and its derivatives, ${ }^{26}$ and finally the highly nucleophilic olefin $10,10^{\prime}$-bi(trispiro)[2.0.2.0.2.1]decylidene (10). ${ }^{27}$

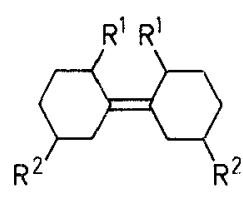

5

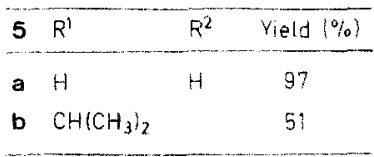

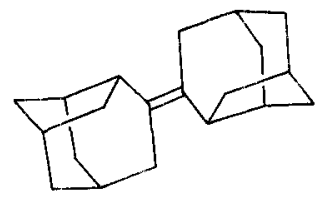

$745 \%$

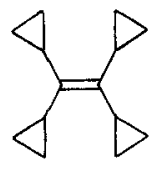

$925 \%$

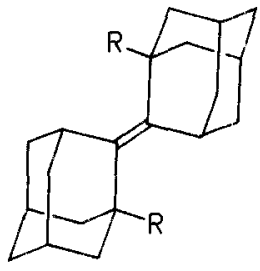

6

\begin{tabular}{ccc}
\hline 6 & $\mathrm{R}$ & Vield $(\%)$ \\
\hline a & $\mathrm{H}$ & 85 \\
b & $\mathrm{CH}_{3}$ & 68 \\
c & $\mathrm{CH}_{2} \mathrm{CH}_{3}$ & 52 \\
\hline
\end{tabular}

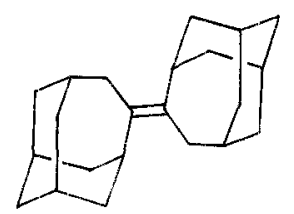

$820 \%$

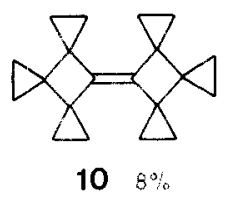

\subsubsection{Preparation of Strained Ethylenes}

The coupling of ketones with low-valent titanium reagent is an effective method for the synthesis of highly strained ethylenes. Several strained ethylenes have been produced by this method (Table 1,2). The yields are generally low, however, alternative synthetic routes have been unsuccessful for some of these compounds.

Table 1. Preparation of Strained Ethylenes

\begin{tabular}{|c|c|c|c|c|}
\hline $\begin{array}{l}\text { Starting } \\
\text { Material }\end{array}$ & Product & Reagent & $\begin{array}{l}\text { Yield } \\
(\%)\end{array}$ & Ref. \\
\hline & & $\begin{array}{l}\mathrm{TiCl}_{3} / \mathrm{K} / \mathrm{THF} \\
\mathrm{TiCl}_{3} / \mathrm{LiAlH}_{4} / \mathrm{THF} \\
\mathrm{TiCl}_{3} / \mathrm{Zn}-\mathrm{Cu} / \mathrm{DME}\end{array}$ & $\begin{array}{l}37 \\
12 \\
94\end{array}$ & $\begin{array}{l}28 \\
29 \\
20\end{array}$ \\
\hline & & $\mathrm{TiCl}_{3} / \mathrm{LiAlH}_{4} / \mathrm{THF}$ & 40 & 30 \\
\hline & & $\begin{array}{l}\mathrm{TiCl}_{4} / \mathrm{Zn} / \mathrm{THF} \\
\mathrm{TiCl}_{4} / \mathrm{LiAlH}_{4} / \mathrm{THF}\end{array}$ & $\begin{array}{l}68^{a} \\
70^{b}\end{array}$ & $\begin{array}{l}31 \\
32\end{array}$ \\
\hline & & $\mathrm{TiCl}_{3} / \mathrm{LiAlH}_{4} \mathrm{THF}$ & $8^{\mathrm{c}}$ & 33 \\
\hline & & $\mathrm{TiCl}_{3} / \mathrm{LiAlH}_{4} \mathrm{THF}$ & 13 & 34 \\
\hline
\end{tabular}

- E-isomer only.

b $E / Z$ ratio $=1: 1$.

$\therefore / Z$ ratio $=12: 1$. 
1-Ethyladamantanone couples to give the strained ethylene $6 c,{ }^{23}$ but neither tert-butyl isopropyl ketone, ${ }^{35}$ nor di-tert-butyl ketone ${ }^{36,37}$ could be coupled to give the corresponding alkene by any of the low-valent titanium species. The reaction of $d$-tertbutyl ketone with $\mathrm{TiCl}_{3} / \mathrm{LiAlH}_{4}$ in refluxing dioxane yield. exclusively di-tert-butyl carbinol, ${ }^{36}$ no C.C-coupling is observed. tert-Butyl cyclopropyl ketone reacts with low-valent tianium to give a complex mixture of products. ${ }^{35} \mathrm{~A}$ small anount of C,C-coupled saturated material can be isolated. demonstrating the limitations of the reaction due to severe steric hindrance. For comparison with alternative alkene syntheses see Section 3.1.4.

\subsubsection{Preparation of Aromatic Olefins}

Sierically uncrowded and crowded stilbene derivatives 12 have been prepared from ketones 11 by a low-valent titanium coupling reaction (Table 2 ).

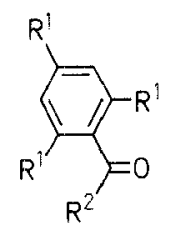

11

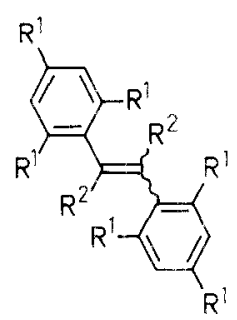

12
Table 2. Coupling of Aryl Ketones 11 to give Stilbenes 12

\begin{tabular}{|c|c|c|c|c|c|c|}
\hline 11 & $\mathrm{R}^{1}$ & $\mathrm{R}^{2}$ & Reagent & $\begin{array}{l}\text { Yield } \\
(\%)\end{array}$ & $\begin{array}{l}E Z \\
\text { ratio }\end{array}$ & Ref. \\
\hline \multirow[t]{3}{*}{$\mathbf{a}$} & $\mathrm{H}$ & $\mathrm{H}$ & $\mathrm{TiCl}_{4} / \mathrm{Zn} / \mathrm{THF}$ & 88 & $1: 4$ & 1 \\
\hline & & & $\mathrm{TiCl} / \mathrm{Zn} /$ dioxane & 98 & $99: 1$ & 2 \\
\hline & & & $\begin{array}{l}\mathrm{TiCl}_{3} / \mathrm{LiAlH}_{4} / \\
\mathrm{THF}^{-}\end{array}$ & 97 & $\sim 85: 15$ & 3 \\
\hline b & $\mathrm{H}$ & $\mathrm{CH}_{3}$ & $\mathrm{TiCl}_{4} / \mathrm{Zn} / \mathrm{THF}$ & 81 & $26: 74$ & 38 \\
\hline c & $\mathrm{H}$ & $\mathrm{CH}_{2} \mathrm{CH}_{3}$ & $\mathrm{TiCl}_{4} / \mathrm{Zn} / \mathrm{THF}$ & 59 & $27: 73$ & 38 \\
\hline d & $\mathrm{H}$ & $\mathrm{CH}\left(\mathrm{CH}_{3}\right)_{2}$ & $\mathrm{TiCl}_{\mathrm{d}} / \mathrm{Zn} / \mathrm{THF}$ & 25 & $88: 12$ & $\begin{array}{l}38 \\
41\end{array}$ \\
\hline e & $\mathrm{H}$ & $\mathrm{C}\left(\mathrm{CH}_{3}\right)_{3}$ & $\mathrm{TiCl}_{\mathrm{a}} \mathrm{Zn} / \mathrm{THF}$ & 45 & $\sim 100: 1$ & 36 \\
\hline f & $\mathrm{CH}_{3}$ & $\mathrm{H}$ & $\mathrm{TiCl}_{4} / \mathrm{Zn} / \mathrm{THF}$ & 82 & $\sim 100: 1$ & 39 \\
\hline g & $\mathrm{CH}_{3}$ & $\mathrm{CH}_{3}$ & $\mathrm{T:Cl} / \mathrm{Li} / \mathrm{THF}$ & 22 & $1: 1.2$ & 40 \\
\hline h & $\mathrm{OMe}$ & $\mathrm{CH}_{3}$ & $\mathrm{TCl}_{3} / \mathrm{Li} / \mathrm{THF}$ & 42 & $1: 1.8$ & 40 \\
\hline
\end{tabular}

The preference for formation of 7 -products of uncrowded stilbenes 12a, 12f, has been attributed to complexation and stabilization of the two aromatic moieties by titanium possible only in the meso-diol form, which further yields the Z-stilbene on deoxygenation. ${ }^{38}$ Whilst $\mathrm{TiCl}_{4} / \mathrm{Zn}$ yields $Z$-products preferentially $(12 \mathbf{a}-\mathbf{e}), E$-stilbene $12 \mathrm{a}$ is formed in the coupling reaction when $\mathrm{TiCl}_{3} / \mathrm{LiAlH}_{4}$ is the reagent. ${ }^{3}$

tert-Butyl phenyl ketone (11 e) yields exclusively the crowded $E$ stilbene $12 \mathrm{e}$, regardless of the reagent used to generate lowvalent titanium; a detailed study of this chemistry has recently been published. ${ }^{41}$ In the coupling of the highly crowded ketones $11 \mathrm{~g}, \mathbf{h}$, formation of ethane derivatives is observed and reduced methylene compounds are isolated as side-products. ${ }^{40}$ Supermesityl aldehyde (11: $\left.\mathrm{R}^{1}=\mathrm{C}\left(\mathrm{CH}_{3}\right)_{3}, \mathrm{R}^{2}=\mathrm{H}\right)$ when reacted with $\mathrm{TiCl}_{3} / \mathrm{LiAlH}_{4}$ couples to give exclusively the ethane derivative 1,2-disupermesitylethane in $52 \%$ yield. ${ }^{42}$ Mesityl tert-butyl ketone and dimesityl ketone ${ }^{35}$ do not give
C,C-coupling products when reacted with low-valent titanium reagents. ${ }^{40,41}$ This shows the limitation of the reaction, as severe steric crowding would be present in the hypothetical coupled products.

Diaromatic ketones, for example, benzophenone, ${ }^{4}$ 9-fluorenone, and 1,1'-dinaphthyl ketone, ${ }^{42}$ on treatment with lowvalent titanium give the corresponding aryl ethylenes in excellent yields. Phenyl 3-pyridyl ketone gives the corresponding ethylene in $31 \%$ yield. ${ }^{43}$ Di- $\omega$-tolyl ketonc yields the tetra- 0 -tolyl eth. ylene along with small amounts of the ethane derivative. ${ }^{44}$ Surprisingly, coupling of the dibenzocycloheptanone 13 using $\mathrm{TiCl}_{4} / \mathrm{Zn}$ does not yield the expected product 14 , but results in the formation of the chiral bridged diphenylanthracene 15 and the ethane derivative $16 .{ }^{45}$
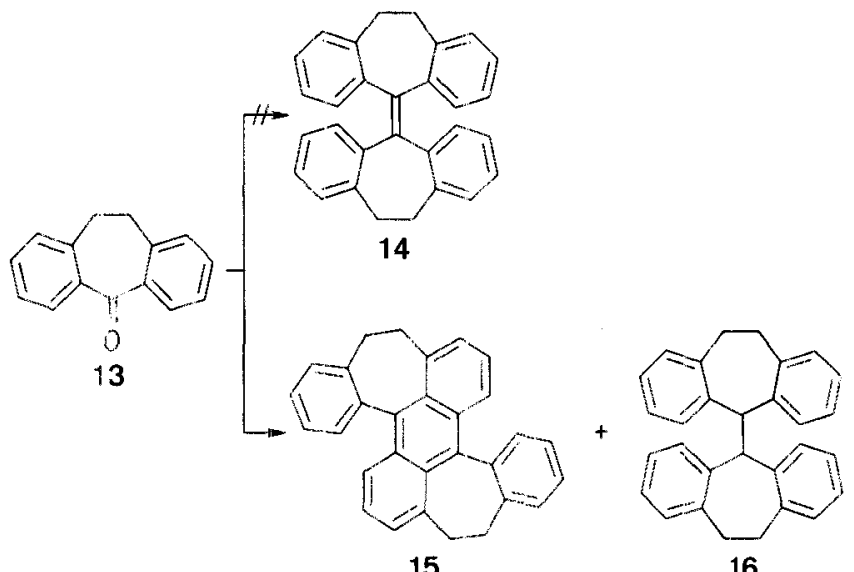

16

Benzylated cyclic ketones 17 can be coupled to give cyclic stilbene derivatives 18 (Table 3 ).

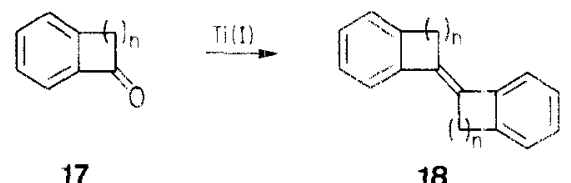

$n=1,2,3,4$

Table 3. Coupling of Ketones 17 to give Cyclic Silbenes 18

\begin{tabular}{llcll} 
n & Reagent & $\begin{array}{c}\text { Yield } \\
(\% / 0)\end{array}$ & $\begin{array}{l}E / Z \\
\text { ratio }\end{array}$ & Ref. \\
\hline 1 & $\mathrm{TiCl}_{3} / \mathrm{LiAlH}_{4} / \mathrm{THF}$ & 62 & $9: 1$ & 46 \\
2 & $\mathrm{TiCl}_{4} / \mathrm{Zn} / \mathrm{THF}$ & 76 & $9: 1$ & 46 \\
3 & $\mathrm{TiCl}_{4} / \mathrm{Zn} / \mathrm{THF}$ & 78 & $7: 3$ & 46 \\
4 & $\mathrm{TiCl}_{4} / \mathrm{Zn} / \mathrm{THF}$ & 38 & $8: 2$ & 39
\end{tabular}

Several alkyl and methoxy derivatives of ketones 17 have been coupled successfully using low-valent titanium reagents. ${ }^{46}$ Derivatives of $18(\mathrm{n}=3)$ are useful starting materials in the preparation of perylene compourds $.^{42}(E)-1-(3,4-D i h y d r o-2,2-$ dimethyl-1( $2 H$ )-naphthalenylidene)-1,2,3,4-tetrahydro-2,2-dimethy naphthalenc (19) and its $Z$-isomer have also been prepared and studied; due to severe crowding of the stilbene system only the $E$-isomer can be isolated in crystalline form because of the very low $Z / E$ barrier of $21 \mathrm{kcal} / \mathrm{mol}$ observed in solution since $Z-19$ rearranges instantaneously to $E-19 .^{47}$ 
<smiles>CC1(C)CCc2ccccc2C1=C1c2ccccc2CCC1(C)C</smiles>

$Z-19$

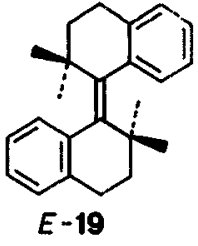

$E-19$

\subsubsection{Mixed Coupling of Carbonyl (iroups}

The intermolecular coupling of identical aldehydes and ketones yields symmetrical olefins. A mixture of two differcnt carbonyl compounds will react generally to a nearly statistical mixture of olefins when subjected to low-valent titanium. ${ }^{48}$ Some ncw olefins have been prepared by this method, e.g. crowded ethylenes 20 from the reaction of pivalaldehyde/corresponding ketone in a 4:1 mole ratio. ${ }^{49}$ The crowded ethylenes $20 \mathrm{a}, \mathrm{b}$ have been used for the determination of thermal barriers to $Z \mid E$ isomerization; 1,2-dimethyl- and 1,2-diethyl-di-tert-butylethylenes (Table 1) have also been used for this purpose. ${ }^{49}$

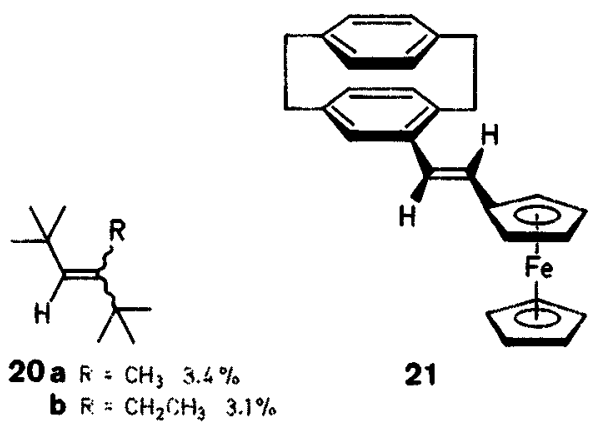

1-(3-[2.2]-Paracyclophano)-2-ferrocenylethylene: (21) can be prepared by mixed coupling of either aldeliyde in $33 \%$ yield. ${ }^{50}$

By applying an excess of one carbonyl compound mixed coupling can be synthetically useful, for example, in the isopropylidenation of carbonyl groups using an excess of acetone. (holestanone (22) gives the mixed coupled product 23 in $54 \%$ yicld: cholestanylidenecholestane is only formed in $29 \%$ yicld. ${ }^{4 *}$ Adamantanone gives the isopropylidene derivative with a yield of $63 \%$ under the same conditions. ${ }^{48}$

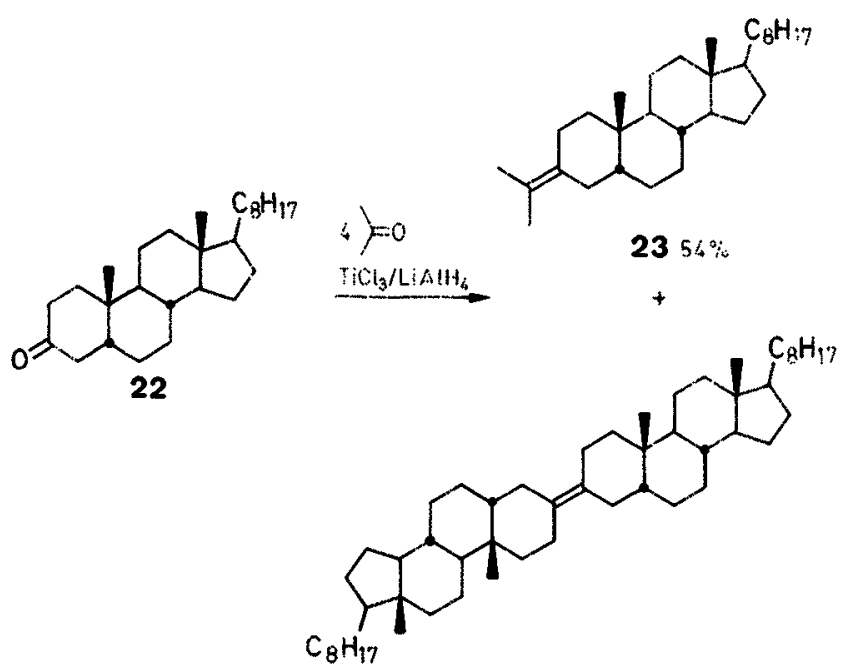<smiles>CC1=CCCC(C)C1=O</smiles>

26

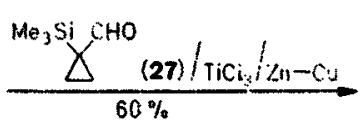<smiles>CC1=CCCC(C)C1=CC1([As])CC1</smiles>

28

It is also possible to couple mixtures of dialkyl- and diaryl ketones (Scheme B). The mixed coupling of equimolecular amounts of benzophenone and cyclohexanone gives 1.1-dihexyl-2,2-diphenylethylenc in $78 \%$ yield, with the self-condensation products tetraphenylethylene and cyclohexyldienecyclohexane in $19 \%$ and $6 \%$ yield, respectively. ${ }^{4 \%}$

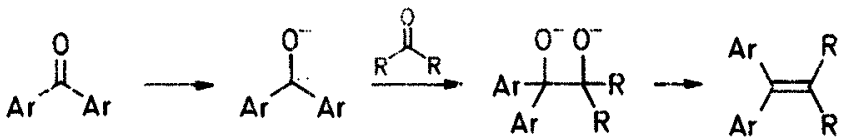

Scheme B

Mechanistically this can be explained in terms of the different reduction potentials of the ketones. As the second reduction polential of diaryl ketones is less negative than the first reduction potential of dialkyl ketones, the initial step is two-electron transfer from low-valent titanium to the diaryl ketone. The dianion thus formed then adds to the dialkyl ketone to give a mixed pinacol product, which is further deoxygenated to yield the alkene. ${ }^{48}$<smiles>[R]c1ccc(C(=O)c2ccc(OCCN(C)C)cc2)cc1</smiles>

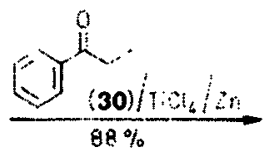

29<smiles>[R]c1ccc(C(=C(CC)c2ccccc2)c2ccc(OCCN(C)C)cc2)cc1</smiles>
31 $\mathrm{R}=\mathrm{H}_{3} \mathrm{OMe}_{2} \mathrm{CHCH}_{2} \mathrm{CH}_{2}, \mathrm{HrCH}_{2} \mathrm{CH}_{2}, \mathrm{Cl}_{3} \mathrm{C}_{6} \mathrm{~F}_{6}, \mathrm{He}_{2} \mathrm{NCH}_{2} \mathrm{CH}_{2}$

Mixed coupling has also been applied in symlhesis of the antitumor agent tamoxifen $(31, \mathrm{R}=\mathrm{H})$ by the coupling of ketories 29 and 30. Several derivatives of tamoxifen (31) have also been prepared starting from the substituted benzophenone 30. 53

\subsubsection{Scope and Limitation of the Coupling Reaction}

The coupling reaction can be compared with two more recent alkene preparations. The Barton-Kellogy method (thiadiazoline method), ${ }^{54}$ makes use of the cycloaddition of thio- or selenoketones 32 to diazoalkanes 33 yielding the five-membered heterocycles 34 , which are subjected to a double extrusion process to give alkenes 35 . 


$$
\begin{aligned}
& \underset{\mathrm{R}^{2^{\prime}}}{\mathrm{R}^{!}}=\mathrm{X}+\mathrm{N}_{2}^{+}=\mathrm{R}_{\mathrm{R}^{4}}^{\mathrm{R}^{3}} \rightarrow \\
& 32 \\
& 33
\end{aligned}
$$

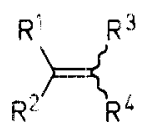

$X=5, s e$

$R^{1}=R^{2}=R^{3}=R^{4}=a\lfloor b y !$ aryi

The disadvantages of the Barton Kellogg method are that; the preparation of the alkenes 35 involves three complicated steps starting from the parent ketone; highly crowded unsymmetrical thiadiazolines can show retro-cycloreversion reactions to yield complex alkene mixtures, ${ }^{56}$ it is not possible to synthesize some of the alkenes cited in Table 1 as again complex product mixtures result. ${ }^{47}$ However, the Barton-Kellogg method allows the synthesis of many unsymmetrical alkenes. ${ }^{54,59}$

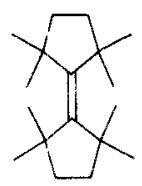

36

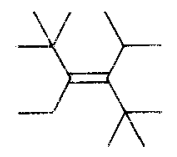

37

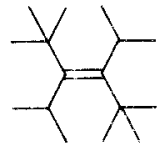

38
It is not possible to prepare tetra-tert-butylethylene by any known method; however, cyclic tied-back derivatives of this alkene, such as $\left(2^{\prime}, 2^{\prime}, 5^{\prime}, 5^{\prime}\right.$-tetramethylcyclopentylidene)-2,2,5,5tetramethylcyclopentane (36), have been prepared. Compound 36 can be prepared by the Barton-Kellogg method ${ }^{55,57}$ it is not possible to prepare 36 by reductive coupling from the ketone by low-valent titanium. ${ }^{42}$ The Barton-Kellogg method has also been applied in the successful synthesis of the extremely crowded alkenes 37 and 38. ${ }^{58}$ 3,4-Di-tert-butyl-2,5dimethyl-3-hexene (38) is the most hindered alkene prepared to date. It has a calculated strain energy of $61.4 \mathrm{kcal} / \mathrm{mol}$. the thermal $Z / E$ barrier is expected to be extremely low. Preparation of $\mathbf{3 7}$ and $\mathbf{3 8}$ using low-valent titanium coupling were unsuccessful. ${ }^{35}$

In general, alkene synthesis by carbene dimerization are hampered by numerous side-reactions. ${ }^{59}$ But synthesis of tetramesitylethylene was only accomplished by carbene dimerization. ${ }^{60} \mathrm{~A}$ newly developed reaction, reductive coupling of thioacetals with molybdenum hexacarbonyl, has not been applied to highly crowded alkenes. ${ }^{62}$

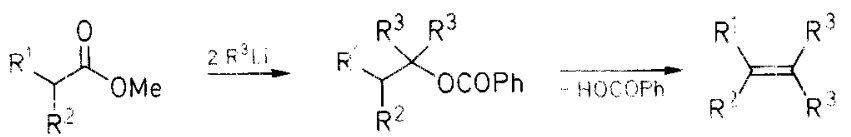

Scheme C

An alternative method (Scheme $\mathbf{C}$ ) allows the preparation of a variety of symmetrical and unsymmetrical alkenes from carboxylic acid derivatives. Tri-tert-butylethylene and tetracyclopropylethylene have been prepared by this route. ${ }^{62}$ However, the reaction is limited in its initial step by the steric crowding of the starting carboxylic acid, for example, 1,2,2-trimethylbutyric acid and its methyl ester do not react with tert-butyllithium. ${ }^{63}$ Thus attempted synthesis of tri-tert-butylmethylethylene failed as the initial step was unsuccessful. However, this alkene has been successfully prepared by another strategy by Krebs et al. ${ }^{57} \mathrm{~A}$ modified version of this method has recently been developed by Olah. ${ }^{64}$ Ketone 39 react with isopropyllithium to give the carbinol 40, which is dehydrated to the alkene 41 without isolation.

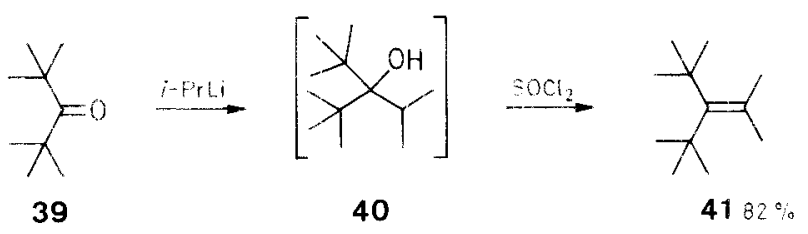

\subsubsection{Selective Coupling of Ketones and Aldehydes 3.1.5.1. Groups with Large Reduction Potentials}

Low-valent titanium coupling methods can tolerate the presence of various functional groups in the molecules to be coupled. Carbon carbon double bonds are generally inert to all low-valent titanium species, and no isomerization is observed. Reports of coupling in the presence of carbon-carbon triple bonds are rare, and a partial hydrogenation seems to occur. Ethers and alcohols are generally stable under coupling conditions; however, 2-alkyl-3-ethoxyacroleins $\mathbf{4 2}$ react to give 2,5dialkyl-2,4-hexadieneals 43 in moderate yields. ${ }^{65}$ Benzyl- ${ }^{60}$ and silyl ethers ${ }^{67}$ generally pose no problems under these reaction conditions. Acetals have also been shown to be stable (see examples given below), as well as alkylvinylsilanes. ${ }^{48}$ Special care must be taken in the workup conditions for acetals.

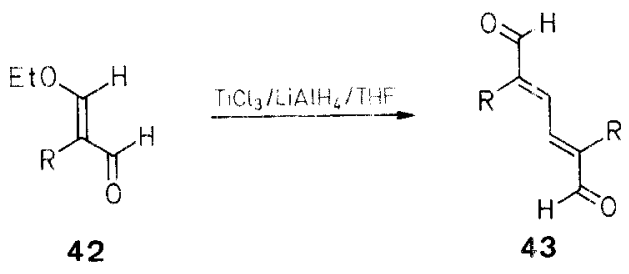

These are also several examples of the stability of secondary and tertiary amines under low-valent titanium coupling conditions. Aromat $c$ halides do not interfer with the couplir $g$ reaction if the correct conditions are used, for example; the coupling of 44 to give $45{ }^{\circ 8}$ and 46 to give $47 .^{69}$

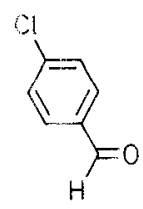

44

46

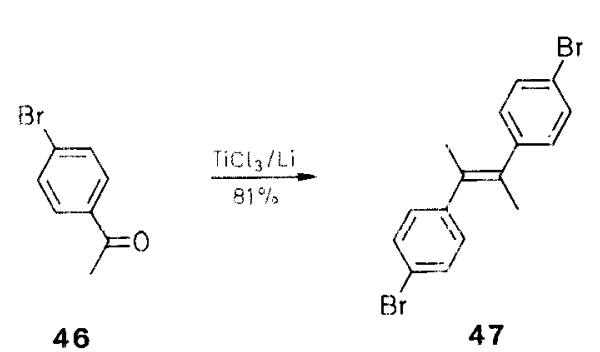

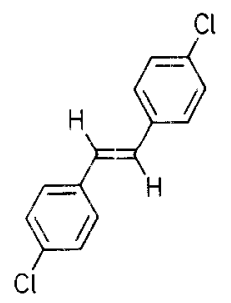

45 $p=$ cyclopentadieryl 
Under normal conditions $\left(\mathrm{TiCl}_{3} / \mathrm{LiAlH}_{4}\right)$ aromatic iodides, bromides and chlorides can also be reduced to arenes. ${ }^{70} \mathrm{~A}$ trifluoromethyl group present in the aryl system does not interfere with the coupling reaction. ${ }^{70}$ Sulfides ${ }^{71}$ and selenides ${ }^{72}$ are also stable towards the reductive power of low-valent titanium. Amides are only stable under special conditions. ${ }^{73}$ Ferrocene units are stable towards titanium tetrachloride and zinc, ${ }^{50}$ for example, acetyl ferrocene can be coupled to the isomeric 2-butene derivatives. ${ }^{36}$

\subsubsection{Groups with Low Reduction Potentials}

Aromatic aldehydes and ketones have been coupled in the presence of adjacent acyloxy, methoxy, methoxycarbonyl and tosyloxy groups using titanium trichloride/zinc copper in dimethoxyethane. ${ }^{74}$ Selected examples for the coupling of aromatic carbonyl compounds 48 to give stilbenes 49 are shown in Table 4

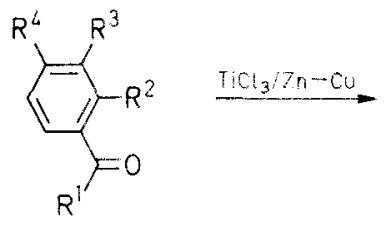

48

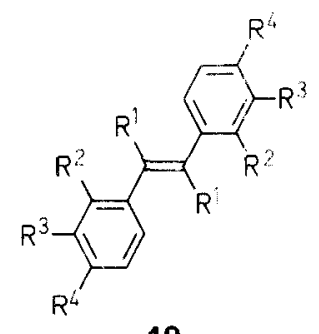

49
Table 4. Reductive Coupling of Aromatic Carbonyl Compound 48

\begin{tabular}{|c|c|c|c|c|c|c|}
\hline 48 & $\mathrm{R}^{\prime}$ & $\mathrm{R}^{2}$ & $\mathrm{R}^{3}$ & $\mathrm{R}^{4}$ & Solvent & $\begin{array}{l}\text { Yield } \\
(\% / \%)\end{array}$ \\
\hline $\mathbf{a}$ & $\mathrm{H}$ & $\mathrm{H}$ & $\mathrm{OAc}$ & $\mathrm{OMe}$ & $\mathrm{DME}^{\mathrm{a}}$ & 87 \\
\hline b & H & $\mathrm{H}$ & $\mathrm{OMe}$ & $\mathrm{OAc}$ & THF & 87 \\
\hline c & $\mathrm{CH}_{3}$ & $\mathrm{H}$ & $\mathrm{H}$ & OAc & $\mathrm{DME}^{\mathrm{a}}$ & 64 \\
\hline d & $\mathrm{H}$ & $\mathrm{H}$ & OTs" & $\mathrm{H}$ & THF & 80 \\
\hline e & $\mathrm{H}$ & $\mathrm{OTs}^{\mathrm{b}}$ & $\mathrm{H}$ & $\mathrm{H}$ & THF & 92 \\
\hline f & $\mathrm{CH}_{3}$ & OTs $^{b}$ & $\mathrm{H}$ & $\mathrm{H}$ & THF & 64 \\
\hline
\end{tabular}

a DME $=$ dimethoxyethane.

${ }^{\text {h }} \mathrm{OTS}=4-\mathrm{CH}_{3} \mathrm{C}_{6} \mathrm{H}_{4} \mathrm{SO}_{3}$.

Noteworthy is the coupling of methyl benzoate using titanium trichloride/magnesium to give benzil $(46 \%)$ and 1,2-dibenzoyl1,2-diphenylethylene $(20 \%){ }^{1}$ Further examples of intramolecular coupling in the presence of ester groups are given later in this review.
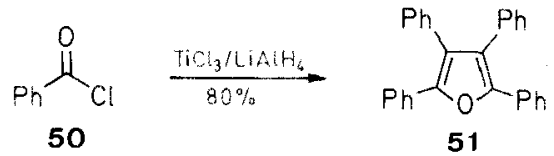

It is also possible to perform a selective coupling reaction in the presence of two different keto groups, if one group can cyclize intramolecularly; this interesting selectivity will be further discussed. Carboxylic acids do react with low-valent titanium. Benzoyl chloride (50) reacted in a one-pot reaction with titanium trichloride/lithium aluminum hydride to give tetraphenylfuran (51) in $80 \%$ yield. ${ }^{70}$ The intermediates in this reaction have been shown to be benzil and 1,2-dibenzylstilbene.

Aromatic nitro compounds yield mixtures of azoarenes and amines, whilst a modification of the reaction conditions gives mixtures of substituted stilbenes and tolanes. ${ }^{70}$

\subsection{Preparation of Gilycols}

Aldehydes and ketones can be coupled to give pinacols with low-valent titanium (see Scheme D) using mild and special reaction conditions: ${ }^{2}$ in general, the reaction is performed at $0 \mathrm{C}$.<smiles>[R]C([R])=O</smiles><smiles>[R]C([R])(O)C([R])(O)C([R])([R])O</smiles><smiles>[R]C([R])(O)[C@@]([R])(O)[AlH2]</smiles>

Scheme D

Diols cannot always be isolated, since deoxygenation can occur very quickly to give the alkene. In general mixtures of mesoand $d, l$-isomers are formed by coupling of unsymmetrical carbonyl compounds. threo-Selectivity has been obtained in the formation of symmetrical glycols using a cyclopentadienylbound titanium(III)-reagent, which is prepared from reaction of cyclopentadienyltitanium(IV) with Grignard reagents. ${ }^{75}$ Some examples of glycol formation using low-valent titanium are shown in Table 5. In all cases tetrahydrofuran was used as the solvent.

Table 5. Intermolecular Coupling of Ketones and Aldehydes.

\begin{tabular}{|c|c|c|c|c|}
\hline $\begin{array}{l}\text { Starting } \\
\text { Material }\end{array}$ & Product & Reagent & $\begin{array}{l}\text { Yield } \\
(\%)\end{array}$ & Ref. \\
\hline & $\mathrm{HO} \mathrm{OH}$ & $\begin{array}{l}\mathrm{TiCl}_{4} / \mathrm{Mg}-\mathrm{Hg} \\
\mathrm{TiCl}_{3} / \mathrm{Mg} \\
\mathrm{TiCl}_{3} / \mathrm{C}_{8} \mathrm{~K}(1: 2)\end{array}$ & $\begin{array}{l}93 \\
45 \\
64\end{array}$ & $\begin{array}{r}16 \\
1 \\
12\end{array}$ \\
\hline & 4 & $\mathrm{TiCl}_{4} / \mathrm{Mg} \sim \mathrm{Hg}$ & 95 & 16 \\
\hline \multirow{5}{*}{$\mathrm{PH}_{\mathrm{H}}$} & \multirow{5}{*}{${ }_{\mathrm{OH}}^{\mathrm{OH}}$} & $\mathrm{TiCl}_{3} / \mathrm{C}_{8} \mathrm{~K}(1: 1)$ & 65 & 42 \\
\hline & & $\mathrm{TiCl}_{4} / \mathrm{Zn}$ & 98 & 2 \\
\hline & & $\mathrm{TiCl}_{4} / \mathrm{Mg}-\mathrm{Hg}$ & 84 & 16 \\
\hline & & $\mathrm{Cp}_{2} \mathrm{TiCl}_{2} /$-PrMgl & $(80: 1)^{\mathrm{a}}$ & 75 \\
\hline & & $\mathrm{Cp}_{2} \operatorname{Ti}(\mathrm{CO})_{2}$ & 50 & 68 \\
\hline & & $\mathrm{TiCl}_{4} / \mathrm{Zn}$ & 91 & 2 \\
\hline & & $\mathrm{Cp}_{2} \mathrm{~T}(\mathrm{CO})_{2}$ & 31 & 68 \\
\hline
\end{tabular}

"Threolerythro.

1,2-Diphenylethane-1.2-diol; Typical Procedure:2

A suspension of zinc powder $(0.59 \mathrm{~g}, 9 \mathrm{mmol})$ in THF $(10 \mathrm{~mL})$ is added slowly to a mixture of benzaldehyde $(0.318 \mathrm{~g}, 3 \mathrm{mmoll}$ and titanium tetrachloride $(0.86 \mathrm{~g}, 4.5 \mathrm{mmol})$ in THF $(20 \mathrm{~mL})$ at -10 under Ar. The yellow solution immediately changes to purple and then turns dark brown. The mixture is stirred for $2 \mathrm{~h}$ at 0 . then $10 \%$ aq. $\mathrm{K}_{2} \mathrm{CO}_{3}$ solution $(10 \mathrm{~mL})$ is added and the solution extracted with $\mathrm{Et}_{2} \mathrm{O}$ $(50 \mathrm{~mL})$. The solvent is evaporated in racuo to give the diol: yield: $0.310 \mathrm{~g}(98 \%)$.

\subsubsection{Mixed Coupling of Carbonyl Compounds}

Corey et al. ${ }^{16}$ have successfully coupled carbonyl compounds to give unsymmetrical or mixed diols. Mixed coupling takes place when a cyclic ketone and a 3 mole excess of a carbonyl compound, such as acetone or acetaldehyde, are reacted with $\mathrm{TiCl}_{3} / \mathrm{Mg}-\mathrm{Hg}$. The unsymmetrical diol can easily be separated from the product mixture by chromatography. For example, an equimolecular mixture of cyclohexanone and acetone gives the mixed diol in $76 \%$ yield. $^{16}$ 
A variation of the pinacol coupling, the reaction of aromatic aldehydes 52 with secondary amines and with titanium tetrachloride/magnesium gives $N, N, N^{\prime}, N^{\prime}$-tetraalkyl-1,2-diaryl-1,2ethanediamines 53 in good yield. The 1:1 mixture of meso- and $d, l$-isomers can be separated by crystallization or chromatography. ${ }^{76}$ Various substituted aromatic aldehydes have been coupled in this way.<smiles>[R]c1ccc(C=O)cc1</smiles><smiles>[R]c1ccc(C([Y20])C([Y20])c2ccc([R])cc2)cc1</smiles>

\section{Intramolecular Coupling of Carbonyl Groups}

\subsection{Preparation of Cycloalkenes and Cyclic Ketones}

Intramolecular coupling of $\alpha,(i)$-dicarbonyl compounds has been applied to the synthesis of cycloalkenes, intramolecular coupling of keto esters gives cyclic ketones. ${ }^{77}$

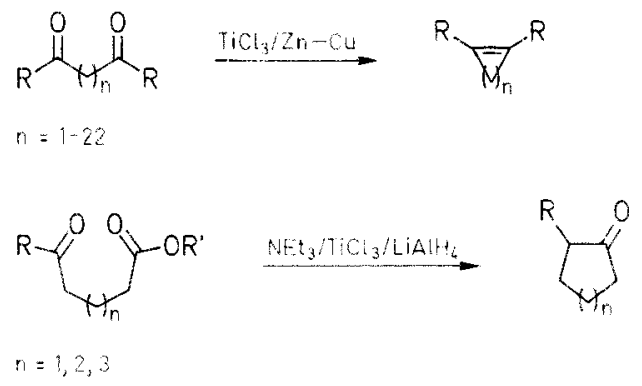

Cycloalkenes can be prepared in all ring sizes up to 22 carbon atoms, the low-valent titanium reagent is usually titanium trichloride/zinc-copper. ${ }^{5}$ Intramolecular keto ester coupling works only well with five-, six- and seven-membered ringsi ${ }^{77}$

Some typical examples of intramolecular coupling of $\alpha,(1)$ diketones are shown in Table 6. In general, tetrahydrofuran is the solvent, and high dilution conditions are used to avoid intermolecular reactions. ${ }^{5}$

Intramolecular coupling of dicarbonyl compounds has recently been optimized using titanium trichloride/dimethoxyethane solvate as the titanium source and zinc copper as the reducing agent. ${ }^{20}$ Yields for cyclic alkenes for medium-sized rings are much higher compared to those from the corresponding acyloin, Thorpe, and Dieckmann condensations. ${ }^{29}$

\section{Macrocyclic Dialdehyde Coupling:}

Dimethoxyethane (DME) was distilled twice from $\mathrm{K}$ metal under an $\mathrm{Ar}$ atmosphere; pentane was distilled from $\mathrm{CaH}_{2}$ and deoxygenated prior to use by purging with $\mathrm{Ar}$ for $10 \mathrm{~min}$. All manipulations were carried out under an atmosphere of $\mathrm{Ar}$ and all transfers were done using Schlenk apparatus.

Preparation of $\mathrm{TiCl}_{3}$ (DME)

$\mathrm{TiCl}_{3}(25.0 \mathrm{~g}, 0.162 \mathrm{~mol})$ is suspended in dry DME $(350 \mathrm{~mL})$, and the mixture refluxed fo: $2 \mathrm{~d}$ under Ar. After cooling to r.t., the solid is filtered under $\mathrm{Ar}$, washed with pentane $(50 \mathrm{~mL})$, dried under vacuum to give fluffy, blue crystalline $\mathrm{TiCl}_{3}(\mathrm{DME})_{2}$, yieid: $32.0 \mathrm{~g}(80 \%)$ that is used in the coupling reaction. The solvate is air sensitive but can be stored indefinitely under $\mathrm{Ar}$ at r.t.

Preparation of Zinc Copper Couple:

$\mathrm{Zn}-\mathrm{Cn}$ couple is prepared ty addition of Zn dust $(9.8 \mathrm{~g}, 150 \mathrm{mmol})$ to $\mathrm{N}_{2}$-purged water $\left(40 \mathrm{~mL}\right.$ ), the slurry is purged with $\mathrm{N}_{2}$ for 15 minu:es,
Table 6. Intramolecular Dicarbonyl Coupling

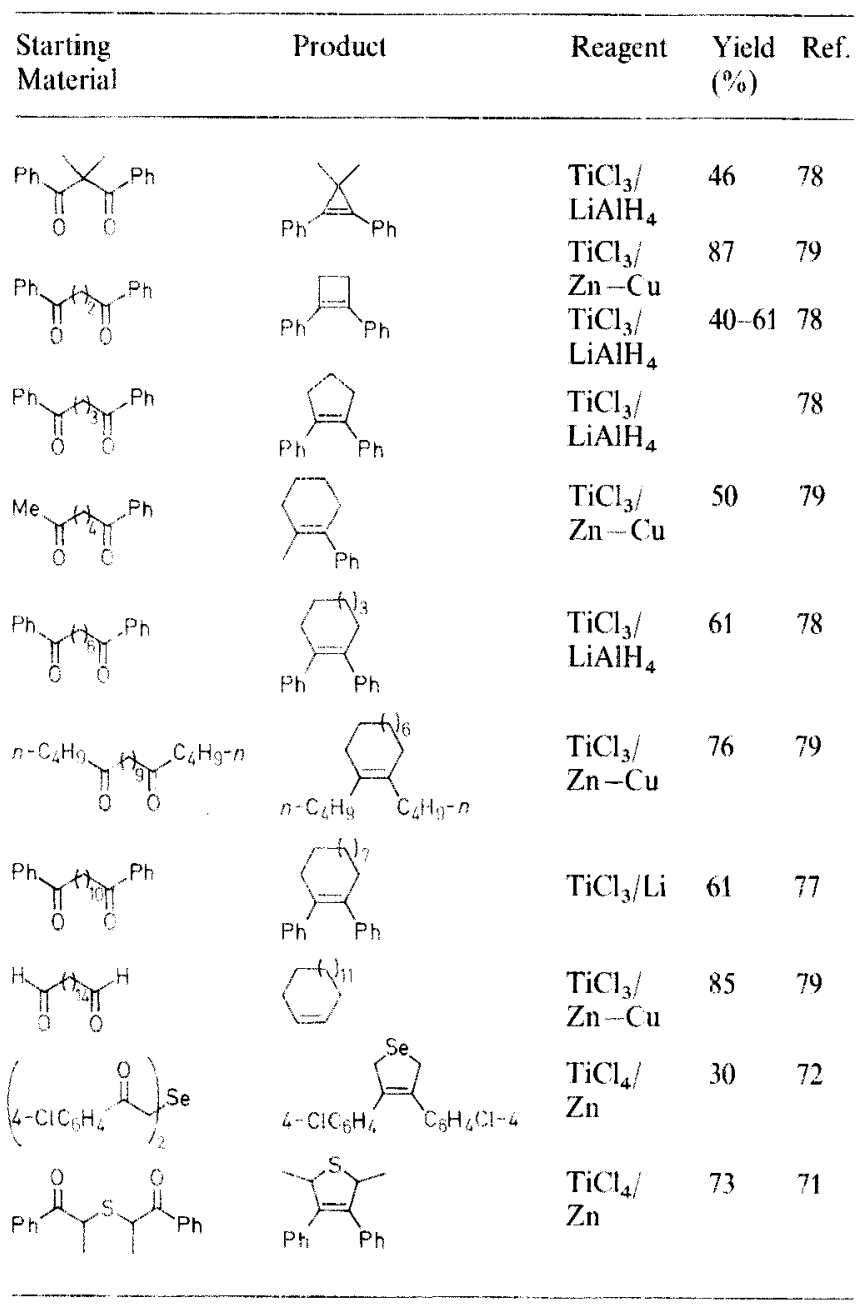

and addition of $\mathrm{CuSO}_{4}(0.75 \mathrm{~g}, 4.7$ mriol). The black slurry is filtered under $\mathrm{N}_{2}$, washed with deoxygenated (nitrogen-purged) water $(10 \mathrm{~mL})$, acetone $(10 \mathrm{~mL})$, and $\mathrm{Et}_{2} \mathrm{O}(10 \mathrm{~mL})$, and dried under vacuum. The couple can be stored indefinitely in a Schlenk tube under $N_{2}$.

\section{1,2-Dimethyleyclotetradecene; ${ }^{20}$ Typical Procedure}

$\mathrm{TiCl}_{3}(\mathrm{DME})_{2}(5.3 \mathrm{~g}, 15.7 \mathrm{mmol})$ and $\mathrm{Zn}-(\mathrm{Cu}$ couple $3.1 \mathrm{~g}, 47.6 \mathrm{mmol})$ were placed in a dry Ar-filled flask, DME $(150 \mathrm{~mL})$ is added, and the mixiure was refluxed for 5 h. 2,15-Hexadecanedione $(0.50 \mathrm{~g}, 2.0 \mathrm{mmol}$ ) in dry DME $(50 \mathrm{~mL})$ is added by syringe pump ove: a period of $35 \mathrm{~h}$ while the reaction temperature is maintained at $80^{\circ} \mathrm{C}$. After addition is complete the mixture is stirred for an additional $8 \mathrm{~h}$. The mixture is cooled to r.t. and pentane $(150 \mathrm{~mL})$ added, the raxture is filtered through Florisil and concentrated under reduced pressure to give 1,2dimethylcyclotetradecene as a mixture of $E / 7$ isomers $(92: 8)$; yield: $360 \mathrm{mg}(32 \%)$.

${ }^{13} \mathrm{C}$-NMR $(E$-isomer) $\delta=18.4,24.1,25.3,25.5,26.3,27.4,33.5,128.5$

Intramolecular coupling has been widely used for the synthesis of compounds with unusual new structures (Table 7) and natural products (Table 8). Low-valent titanium coupling of the 4.10-dioxobicyclo [5.5.0] dodeca-17)ene (54) failed to give the novel compound $\mathbf{5 5}$, since further rearrangement is too fast. ${ }^{80}$

In the synthesis of natural products, low-valent titanium coupling has also been successfully used for the synthesis of the following compounds: hirsutene $\left(\mathrm{TiCl}_{3} / \mathrm{K}, \mathrm{THF}\right){ }^{81}$ bicyclogermacrene ( $\mathrm{TiCl} / \mathrm{Zn}-\mathrm{Cu}, \mathrm{DME})$; $^{82}$ lepidozene $\left(\mathrm{TiCl}_{3} / \mathrm{Zn}-\mathrm{Cu}\right.$, DME); ${ }^{82}$ compactin $\left(\mathrm{TiCl}_{3} / \mathrm{C}_{8} \mathrm{~K}\right.$, DME); ${ }^{83}$ cannithrene II $\left(\mathrm{TiCl}_{3} / \mathrm{Zn}-\mathrm{Cu}, \mathrm{THF}\right){ }^{84}$ the taxane skeletone $\left(\mathrm{TiCl}_{3} / \mathrm{Zn}-\mathrm{Cu}\right.$, DME) ${ }^{85}$ isoamijol, ${ }^{86}$ ceroplastol $\left(\mathrm{TiCl}_{3} / \mathrm{Zn}-\mathrm{Cu}, \mathrm{DME}\right) ;{ }^{87}$ and strigol (TiCl $/ 2 / \mathrm{Zn}-\mathrm{Cu}, \mathrm{DME}){ }^{88}$ Selective coupling has also been 
Table 7. Synthesis of Unusually Structured Compounds.

\begin{tabular}{|c|c|c|c|c|}
\hline $\begin{array}{l}\text { Starting } \\
\text { Material }\end{array}$ & Product & Reagent & $\begin{array}{l}\text { Yield } \\
(\%)\end{array}$ & Ref. \\
\hline & & $\mathrm{TiCl}_{3} / \mathrm{K} / \mathrm{DME}$ & 13 & 90 \\
\hline & & $\begin{array}{l}\mathrm{TiCl}_{4} / \mathrm{Zn} / \text { pyridine/ } \\
\mathrm{THF}\end{array}$ & 40 & 91 \\
\hline & & $\mathrm{TiCl}_{4} / \mathrm{Zn} / \mathrm{THF}$ & 95 & $y_{2}$ \\
\hline & & $\mathrm{TiCl}_{4} / \mathrm{Zn} /$ dioxane & 90 & 93 \\
\hline & & $\mathrm{TiCl}_{3} / \mathrm{Li} / \mathrm{DME}$ & 56 & 94 \\
\hline & & $\begin{array}{l}\mathrm{TiCl}_{3} / \mathrm{LiAlH}_{4} / \\
\mathrm{DMF}\end{array}$ & 35 & 95 \\
\hline & & $\begin{array}{l}\mathrm{TiCl}_{3} / \mathrm{LiAlH}_{4} / \\
\mathrm{THF}\end{array}$ & 77 & 96 \\
\hline & & $\begin{array}{l}\mathrm{TiCl}_{3} / \mathrm{LiAlH}_{4} / \\
\mathrm{THF}\end{array}$ & 35 & 97 \\
\hline & & $\mathrm{TiCl}_{4} / \mathrm{Zn} / \mathrm{THF}$ & 32 & 98 \\
\hline & & $\begin{array}{l}\mathrm{TiCl}_{3} / \mathrm{LiAlH}_{4} / \\
\mathrm{THF}\end{array}$ & 14 & 99 \\
\hline & & $\begin{array}{l}\mathrm{TiCl}_{3} / \mathrm{LiAlH}_{4} / \\
\mathrm{THF}\end{array}$ & 32 & 99 \\
\hline & & $\begin{array}{l}\mathrm{TiCl}_{3} / \mathrm{Zn}-\mathrm{Cu} / \\
\mathrm{DME}^{-}\end{array}$ & 24 & 100 \\
\hline & & $\begin{array}{l}\mathrm{TiCl}_{3} \mathrm{Zn}-\mathrm{Cu} / \\
\mathrm{DME}\end{array}$ & 90 & 101 \\
\hline & & $\begin{array}{l}\mathrm{TiCl}_{3} \mathrm{Zn}-\mathrm{Cu} / \\
\text { DME }\end{array}$ & 82 & 102 \\
\hline & & $\begin{array}{l}\mathrm{TiCl}_{4} / \mathrm{Zn} / \text { pyridine/ } \\
\mathrm{THF}\end{array}$ & $2-10$ & 803 \\
\hline & & $\begin{array}{l}\mathrm{TiCl}_{4} / \mathrm{Zn} / \text { pyridine } / \\
\mathrm{THF}^{2}\end{array}$ & 16 & 104 \\
\hline
\end{tabular}


applied to the synthesis of estrone; ${ }^{89}$ intramolecular coupling of the aldehyde group in the intermediate $\mathbf{5 6}$ occurs faster at the ketone group in the tetralone moiety, than with the cyclopentanone moiety, to give 5?.

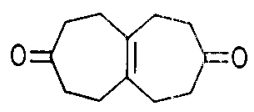

54

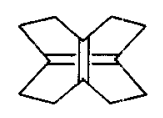

55<smiles>COc1ccc2c(c1)CCC1C2CCC(=O)[C@@]1(C)C=O</smiles>

56<smiles>COc1ccc2c(c1)CCC1C3=CC[C@]4(C)C(=O)CCC4C3CC21</smiles>

57
Table 8. Synthesis of Natural Products

\begin{tabular}{lll}
$\begin{array}{l}\text { Starting } \\
\text { Material }\end{array}$ & Product & $\begin{array}{l}\text { Yield } \\
(\%)\end{array}$ \\
\hline
\end{tabular}

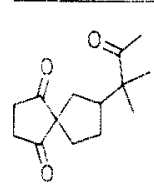<smiles>CC1=C(C)C(C)(C)C(C/C=C(/C)CC/C=C(/C)CO)CC1</smiles><smiles>C=C(C)C(CC=O)CC/C(C)=C/CCC(C)=O</smiles><smiles>C=C(C)C(C/C=C(/C)CCC)CCC</smiles><smiles>CC=CC(C)(C)/C=C/C/C(C)=C/CCC(C)=O</smiles><smiles>CC1=CCC=CCC(C)(C)CC=C1</smiles><smiles>C=C(C)CCC(C)=CCC(C)=O</smiles><smiles>CC1=CCC(C(C)(C)C)CCC(C)=CC1</smiles><smiles>CC(=CCC(C)=CCC(C)(C)C)CC=CCC(C)C</smiles>

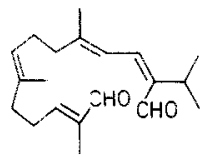

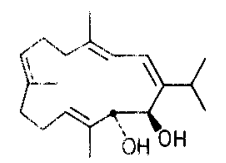

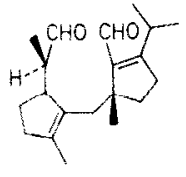<smiles>CC1=C2CCC(C)[C@@H](C)/C=C\C3=C(C(C)C)CC[C@]3(C)[C@H]2C1</smiles>

$57^{\mathrm{a}}$

$7^{a}$ 106

$60^{a}$ 108

a Reagent: $\mathrm{TiCl}_{3} / \mathrm{Zn}-\mathrm{Cu} / \mathrm{DME}$.

b Reagent: $\mathrm{TiCl}_{3} / \mathrm{Zn} / \mathrm{THF}$.<smiles>C=C(C)CCCC(C)=CCCC(C)(C)CC=O</smiles>

Intramolecular coupling of keto esters to give cyclic ketones has not been frequently applied compared to dicarbonyl coupling of aldehydes or ketones. ${ }^{5,77}$ Cyclic coupling of keto esters 58 yields cyclic ketones $59(n=3-8)$, whilst bicyclic ketones 61 can be synthesized from the cyclohexanone derivativas $60(\mathrm{R}=\mathrm{H}$. $\mathrm{n}=2-6,11 ; \mathrm{R}=t-\mathrm{C}_{4} \mathrm{H}_{9}, \mathrm{n}=1$ ).

The key step in the total synthesis of $\gamma$-caryophyllene is the intramolacular coupling of the keto ester $\mathbf{6 2}$ to give the ketone 63, which is further methylated. ${ }^{112}$ This is the only example of a double bond $E / Z$ isomerization by low-valent titanium.

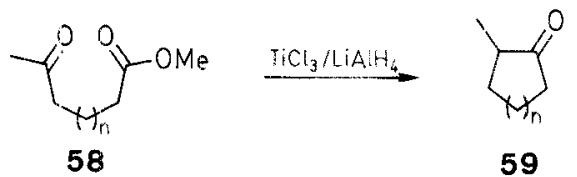<smiles>[R]C1CCC(=O)C(C=CC(=O)OCC)C1</smiles>

60

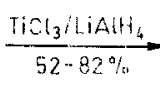<smiles>[R]C1CCC2C(=O)CC2C1</smiles>

61<smiles>CCCCC/C(C)=C\CCC(=O)OCC</smiles>

62<smiles>C/C1=C/CCC(=O)C2CC(C)(C)C2CC1</smiles>

63

\subsection{Preparation of Cyclic Diols}

The reaction of $x,(1)$-dialdehydes 64 ( $\mathrm{n}=1,3,5,7,9$ ) with lowvalent titanium can be used for synthesis of cyclic di-sec-diols 64 in good yields. ${ }^{10}$ The cis/trans ratio of the cyclic glycols is dependent upon the ring size.

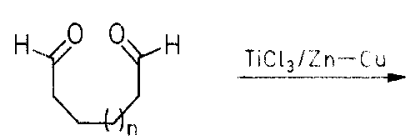

64

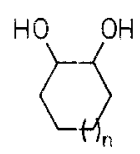

65 $n=3,3,5,7,9$

Two further intramolecular coupling reactions should be mentioned, the formation of the tricyclic diols $67^{16}$ and $69^{11^{13}}$ from 66 and 68 , respectively.

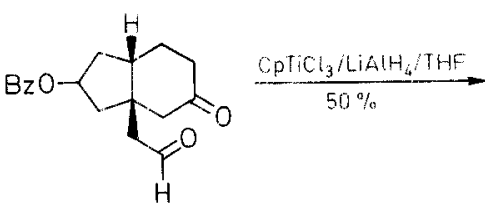

66

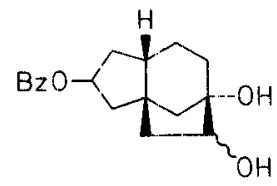

67

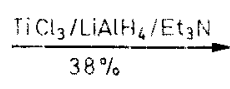<smiles>O=C(O)C(=O)CCC1CCCC12CCCC2=O</smiles>

$\frac{\mathrm{TiCl}_{3} / \mathrm{LiAHH}_{4}}{25 \%}$<smiles>OC12CCCC1C13CCCC1C2(O)CCC3</smiles> 


\section{Reductive Eliminations}

\subsection{Deoxygenation of Glycols}

Glycols can be deoxygenated by low-valent titanium species, some stereoselectivity is observed; for example, in the deoxygenation of meso- and d,l-5,6-decadiols (70) to isomeric 5decenes $71 .^{4}$

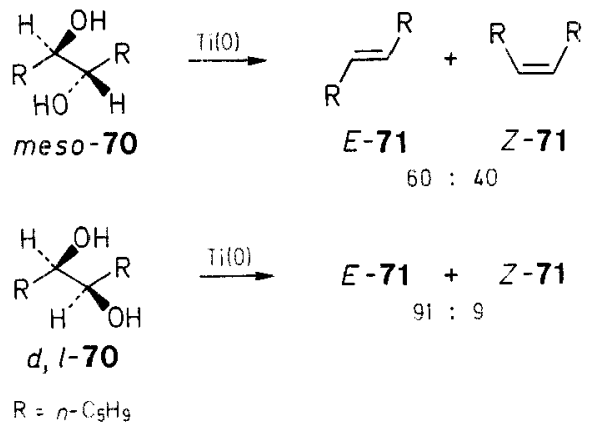

Polycyclic 1,2-diols can only be deoxygenated if the hydroxy groups are as cis-oriented, binding together to a common titanium metal surface (see Scheme E). cis-9,10-Decalindiol (72) is deoxygenated to 9,10 -decalene (73), the $\operatorname{trans}$-isomer is completely inert to deoxygenation by low-valent titanium. ${ }^{4}$
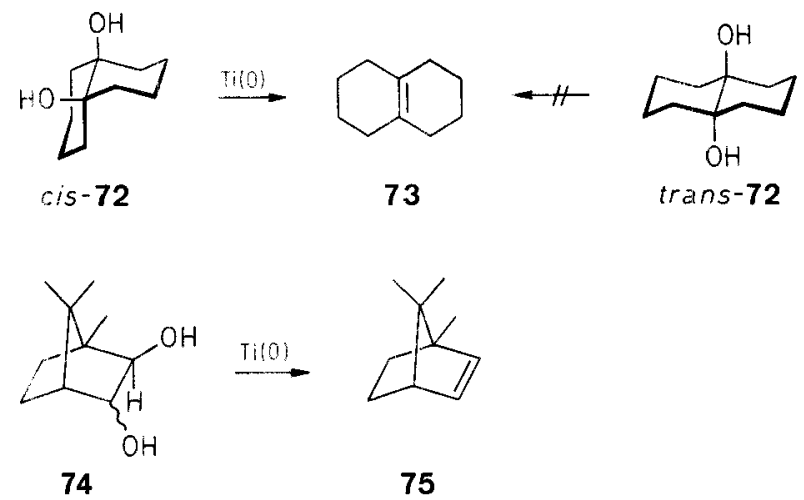

Scheme E

1,2-Adamantandiol is not deoxygenated by low-valent titanium, even though both hydroxy groups can bind to a common metal surface. ${ }^{4,42}$ Deoxygenation would yield the highly strained adamantene, which would be energetically unfavorable. Both isomeric 2,3-hydroxybornanes 74 are deoxygenated to the olefin norbornene (75) with low-valent titanium. ${ }^{4}$

\subsection{Reductive Elimination of Other Groups}

Several functional groups can be successfully subjected to reductive elimination by low-valent titanium species. Oxiranes. for example stilbene oxide (76) ${ }^{14}$ and 1,2-epoxycyclohexane (77), are reduced to the corresponding alkenes with moderate yields. Low-valent titanium species generated from titanocene dichloride/magnesium can be used for the deoxygenation of oxiranes with high selectivity (in the presence of ester groups) and stereoselectivity (with retention of configuration) in high yield $(\sim 90 \%){ }^{115}$ The bromohydrin trans-2-bromo-1-hydroxycyclooctane (78) is converted to cyclooctene in $96 \%$ yield by low-valent titanium. ${ }^{25}$ This reaction has been applied to a number of bromohydrins, which were converted to the corresponding alkenes. ${ }^{25}$

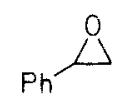

76<smiles>C1CCC2OC2C1</smiles>

77

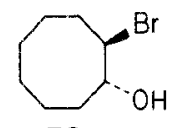

78
Cyclic endo-peroxides, for example 79, give 1,3-dienes on treatment with low-valent titanium. ${ }^{110}$

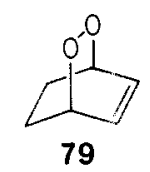<smiles>C[C@H](O)CC(O)(P)P</smiles>

80

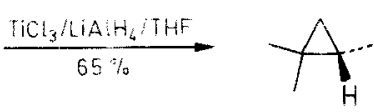

81
1,3-Alkanediols, such as $\mathbf{8 0}$ yield the 1,3-coupled product $\mathbf{8 1}$ with inverted configuration. ${ }^{117}$

Diallylic 1,4-diols, for example 82 (and its cis-isomer). yield 1,3dienes on treatment with low-valent titanium. ${ }^{117}$

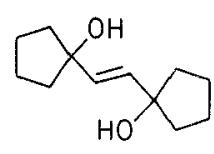

82

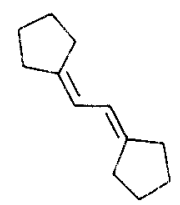

83
$N$-Hydroxyamines 84 are decxygenated with low-valent titanium to give enamines $85 .^{118}$ Aromatic nitro compounds give the corresponding coupled azo compounds in good yield. ${ }^{44}$

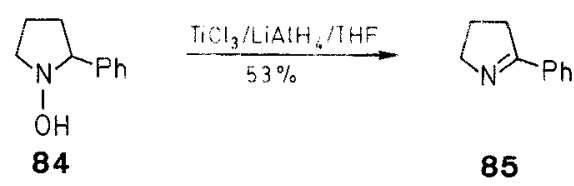

Synthesis of novel benzenoid molecules by low-valent titanium deoxygenation should be mentioned. ${ }^{119}$

\section{Alkylidenation of Carbonyl Groups}

\subsection{Methylenations}

Carbonyl groups of aldehydes, ketones, esters, amides, and acyl amides 86 can be efficiently methylenated to compounds 87 with dicyclopentadienyl titanium methylene complex (Tebbe reagent). ${ }^{120,121}$ This is prepared from the reaction of two equivalents of trimethylaluminum with dicyclopentadienyltitanium(IV) dichloride. ${ }^{121}$ An alternative more convenient method developed by Grubbs ${ }^{122}$ uses $\mathrm{TiCl}_{3} / \mathrm{Zn} / \mathrm{CH}_{2} \mathrm{Cl}_{2}$.

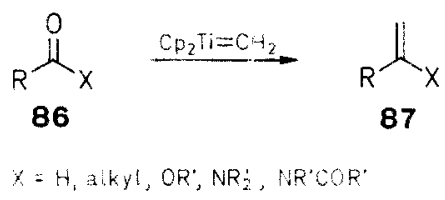

The reaction is synthetically useful for the methylation of hindered or base sensitive ketones and offers advantages over the classical Wittig reaction. Keto esters can be selectively methylenated at the keto group. 
The dicyclopentadienyltitanium-methylene complex can be regarded as the Lewis acid part of the Lewis acid-base complex first formed from the reagents (Scheme F). ${ }^{18}$

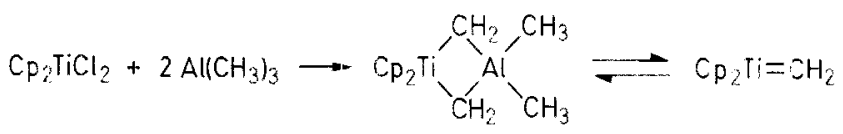

Scheme F

The complex is a Schrock-type, with a 16 e configuration. ${ }^{13}$ Its polarization results in an electrophilic metallic centre and a nucleophilic carbon centre. The same complex can also be formed from titanacyclobutanes (Scheme F). ${ }^{120}$

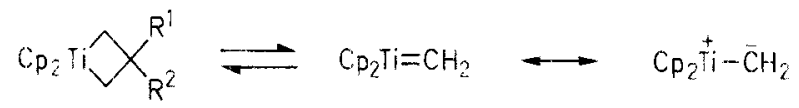

Scheme G

The reaction proceeds by a mechanism analogous to that of the Wittig reaction leading to an oxatitanacyclobutane derivative. which undergoes cycloreversion to give the methylene compound (Scheme H).

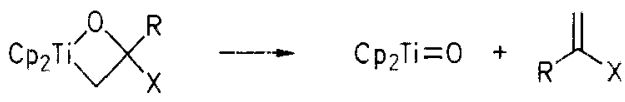

Scheme H

Five typical examples of the methylenation of esters and lactones are summarized in Table 9. Entries 1-4 were performed with Tebbe's reagent, ${ }^{121}$ the methylenation of the cyclic carbonate leading to the ketenc acetal (entry 5) with Grubbs' reagent (dicyclopentadienyltitanacyclobutane). ${ }^{122}$ The use of the latter is strongly recommended if Lewis acid labile starting materials or products are used. No racemization of chiral products is observed with this reagent.

Table 9. Methylenations of Esters and Lactones

\begin{tabular}{|c|c|c|c|c|}
\hline Entry & $\begin{array}{l}\text { Starting } \\
\text { Material }\end{array}$ & Product & $\begin{array}{l}\text { Yield } \\
(\%)\end{array}$ & Ref. \\
\hline 1 & & & 89 & 121 \\
\hline 2 & & & 96 & 121 \\
\hline 3 & & & 87 & 121 \\
\hline 4 & & & 81 & 121 \\
\hline 5 & & & 56 & 122 \\
\hline
\end{tabular}

\section{Preparation of Tebbe's Reagent: ${ }^{-121}$}

Neat $\mathrm{AlMe}_{3}(42 \mathrm{~mL}, 0.2 \mathrm{~mol})$ is added via canula te a suspension of dicyclopentadienyltitanium dichloride $(50 \mathrm{~g}, 0.2 \mathrm{~mol})$ in toluene $(200 \mathrm{~mL})$ under a dry $\mathrm{N}_{2}$-atmosphere with exclusion of moisture. Evolutior of $\mathrm{CH}_{4}$ starts immediately. The red solution is stirred for $48 \mathrm{~h}$, while all volatiles are removed by vacuum distillation into a cold trap (Caution: all aluminum alkyls react viclently with protic media!).

To the red precipitate is added an equimolecular amount of $\mathrm{AlMe}_{3}$ $(42 \mathrm{~mL})$ in toluene $(100 \mathrm{~mL})$. The resulting solution is iltered through a pad of Celite supported on a coarse frit and concentrated to the point of saturation $(\sim 160 \mathrm{~mL}$ total volume). The saturated solution is carefully layered with an equal volume of hexane and allowed to stand undisturbed at $-20^{\circ}$ for $2-3$ days. The supernatant is removed via cannula and the red crystalline mass is washed with petroleurr ether (bp $60 \mathrm{C}$ at $-20 \% 3 \times 10 \mathrm{~mL}$ ). The solids are dried under high vacuum. Yields are in the range of $30-35 \mathrm{~g}(53-61 \%)$.

Methylenation of Carbonyl Compounds; General Procedure: ${ }^{121}$ To a solution of the carbonyl compound ( 1 mmol) in THF $(3 \mathrm{~mL})$ is added Tebbe complex $(0.5 \mathrm{M})$ in toluene $(2 \mathrm{~mL}$ ). After 30$) \mathrm{min} \mathrm{Et}_{2} \mathrm{O}$ (ca $10 \mathrm{~mL}$ ) is added, and then $0.1 \mathrm{M} \mathrm{aq} . \mathrm{NaOH}$ (10 drops) is slowly added to destroy the active aluminum compounds. The deep red reaction mixture is dried $\left(\mathrm{Na}_{2} \mathrm{SO}_{4}\right)$ filtered, hrough Celite and concentrated in vacue. The crude product is purified by shromatography on basic alumina cluting with $2.5 \% \mathrm{Et}_{2} \mathrm{O}$ in pentane.

Vinyl erol ethers can be prepared from esters, amides are converted to enamines. ${ }^{123}$ Acid chlorides and anhydrides are converted into titanium enolate complexes which react further by aldol-type chemistry. ${ }^{124}$ The reaction of phenylacetyl chloride $\mathbf{( 8 8 )}$ ) with the Tebbe reagent forms the titanium enolate 89 which reacts with benzaldehyde to give the $\beta$-hydroxy ketone $90 .{ }^{124}$

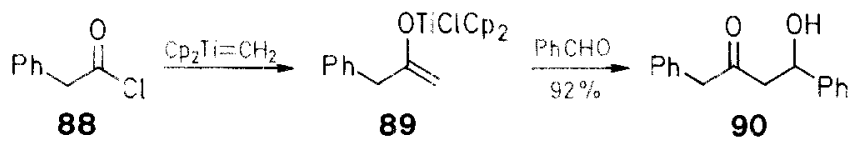

This reaction has found a broad application in organic synthesis, including synthesis of natural products, which cannot be covered here in detail. ${ }^{125}$ A typical example is the synthesis of $( \pm)-4^{9,12}$-capnellene $(96)$ via the adducts $91,92 .{ }^{126}$
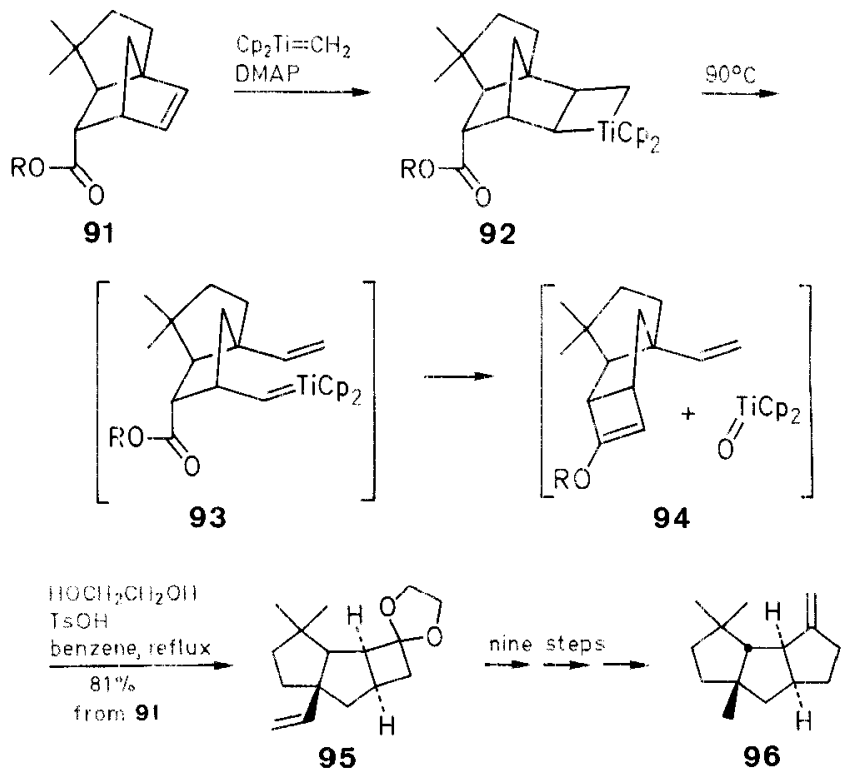
The preparation of substituted allenes 99 by reaction of an allene 97 with a ketone 98 in the presence of Cirubbs' reagent has proved to be a very useful synthetic method (Table 10). ${ }^{127}$

Table 10. Synthesis of Substituted Allenes 99 with Grubbs' Reagent

\begin{tabular}{|c|c|c|c|}
\hline & $\begin{array}{l}R^{\prime} \\
R^{\prime}=-=\end{array}$ & $\mathrm{p}^{\mathrm{m}} / \mathbf{9 8} / \mathrm{m} / \mathrm{lot}$ & $f^{2}$ \\
\hline 97 & $\mathbf{R}^{1}$ & 98 & Yield $(\%)$ \\
\hline $\mathbf{a}$ & $\mathrm{H}$ & benzophenone & 58 \\
\hline b & $\mathrm{CH}_{3}$ & 2-adamantanone & 75 \\
\hline c & $\mathrm{CH}_{3}$ & 2-naphthaldehyde & 53 \\
\hline d & $\mathrm{Ph}$ & cyclopentanone & 72 \\
\hline
\end{tabular}

\subsection{Alkylidenations}

The low-valent titanium species prepared from the reaction of titanium tetrachloride and zinc does not only couple carbonyl compounds to alkenes and 1.2-diols; in the presence of 1.2dihalo-1-alkenes, alkylidenation of the carbonyl group is observed. ${ }^{126}$ Various esters 100 have been converted by this reagent into the corresponding alkenyl ethers 101 with high Zselectivity Table $11 .{ }^{128}$

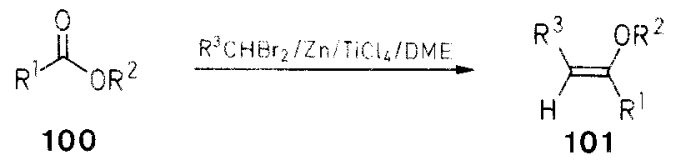

5-Methoxyundecenc; Typical Procedure: ${ }^{129}$

A solution of $\mathrm{TCl}_{4}(1.0 \mathrm{M}, 4.0 \mathrm{mmol})$ in $\mathrm{CH}_{2} \mathrm{Cl}_{2}$ is added at 0 to $\mathrm{THF}$ $(10 \mathrm{~mL})$ under Ar. To the yellow solution at $25^{\circ}$ is added TMEDA $(1.2 \mathrm{~mL}, 8.0 \mathrm{mmol})$ and the mixture is stirred at 25 for $10 \mathrm{~min}$. Zn dust $(0.59 \mathrm{~g}, 9.0 \mathrm{mmol})$ is added to the mixture. The color of the suspension turns from brownish-yellow to dark greenish-blue in a slightly exothermic process. The mixture is stirred at 25 for $30 \mathrm{~min}$, a solution of methyl pentanoate $(0.12 \mathrm{~g}, 1.0 \mathrm{mmol})$ and 1,1 -dibromohexane $(0.54 \mathrm{~g}$, $2.2 \mathrm{mmol})$ in THF $(2 \mathrm{~mL})$ is added to the mixture. The color of the resulting mixture gradually turns dark brown while being stirred at 25 for $2 \mathrm{~h}$. The mixture is cooled to $0^{\circ} \mathrm{C}$ and sat. aq. $\mathrm{K}_{2} \mathrm{CO}_{3}(1.3 \mathrm{~mL})$ is added. The mixture is stirred at 0 for another $15 \mathrm{~min}$, and then diluted with $\mathrm{I}_{2} \mathrm{O}$ and passed rapidly through a short column of basic alumina (activity III) elating with $\mathrm{Et}_{2} \mathrm{O} / \mathrm{Et}_{3} \mathrm{~N}(200: 1,100 \mathrm{~mL}$ ). The resulting clear solution is concentrated and the residue is purified by column chromatography on basic alumina (activity III) eluting with pentane to give the desired 5-methoxy-undecene; yield: $0.18 \mathrm{~g}(96 \%), Z / E=91: 9$.

\section{Conclusions and Summary}

The reductive coupling of aldehydes and ketones by low-valent titanium species (McMurry reaction) has greatly extented the standard potential of the olefin synthesis. In general, symmetrical 1,2-dialkyl-, tetraalkyl- and tetraarylethylenes are obtained in good to excellent yields. Synthesis of some unsymmetrical olefins has been achieved by mixed coupling. Mostly stereoselectivity cannot be controlled, similar to other olefin syntheses. The preparation of many new highly crowded ethylenes and stilbenes has been accomplished by this method. But neither di-tert-butyl nor tert-butyl isopropyl ketone can be coupled showing the steric limitation of the reaction.

Intramolecular coupling is also possible, allowing the preparation of several new unusually structured cyclic compounds as well as a great variety of natural products. The reaction can also be performed in the presence of some other reducible moieties like halogen, methoxycarbonyl and sulfonyl groups. Using special conditions glyco $\mathrm{s}$, which are formed as primary products of the coupling reaction, can be prepared. The titanium methylene complexes discovered recently by Tebbe and by Grubbs are synthetically useful for methylenations of various carbonyl groups, including esters and other carboxylic acid derivatives. extending the potential of the Wittig reaction.

Low-valent titanium species are also very versatile reagents for syntheses of glycols; the alternate reagents like low-valent vanadium, ${ }^{7.130)}$ samarium ${ }^{1.31}$ and zinc-copper in the presence of ultrasonic treatment ${ }^{1.32}$ have only been applied in more special cases.

Addendum. I would like to thank Prof. J.E. McMurry for valuable discussions and an exchange of information. A review written by Prof. J.E. MeMurry about the same topic will appear shortly in Chem. Rev.

Reccived: 29 March 1989; revised: 29 August 1989

(1) Tyrlik, S., Wolochowicz, I. Bull. Soc. Chim. Fr. 1973. 2147.

(2) Mukaiyama, T., Sato, T.. Hanna, J. Chem. Leu. 1973. 1041

(3) McMurry, J.E., Flening, M.P. J. Am. Chem. Sw. 1974, $96,4708$.

(4) McMurry, J.E., Fleming, M.P. J. Org. Chom. 1976, 4l, 896: McMurry, J. E., Fleming. M.P., Kees. K. L.. Krepski, L. R. I. Org. Chem. 1978, 43, 3255.

(5) McMurry, J.E. Ace. Chem. Res. 1983, 16. 405

(6) Lenoir, D. Synthesis 1977, 553.

(7) Lai, Y.H. Org. Prep. Proced. 1980, 12, 361.

(8) Welzel, P. Nachr. Chem. Tech. Lab. 1983, 31,814.

(9) Auderset, P.C., Gartenmann, T.C.C., Gesing, E.R.F. Kontukte (D)armstadt) $1985,3,14$.

Dang, Y, Geise, H, J, Janssen Chimica 4cta 1989. vol. 6. no. 3, 3.

Table 11. Alkylidenation of Esters 100 to Enol Ethers 101

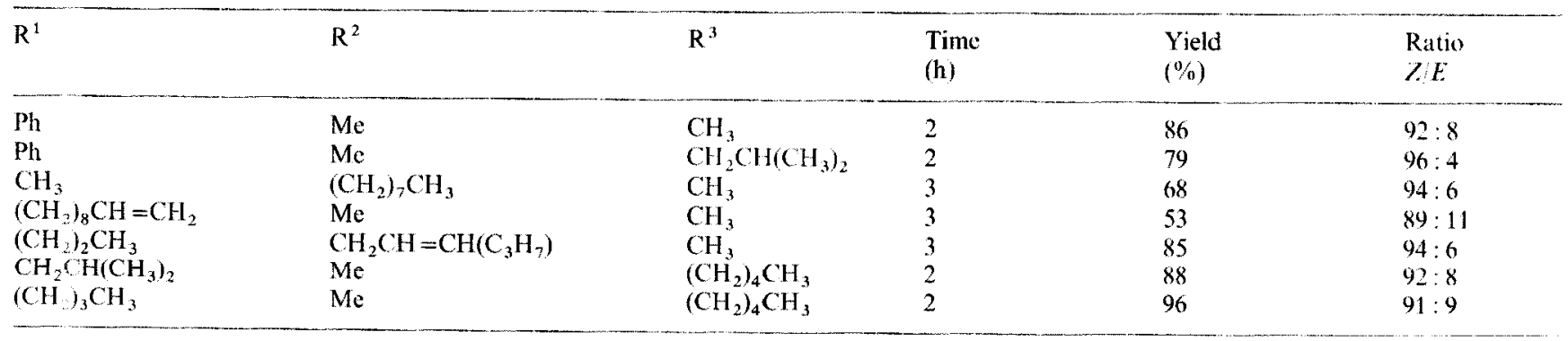


(10) Dams, R., Malinowski, M., Geise, H.J, Bull. Soc. Chim. Be/ges 1981, 90. 1141

Dams, R., Malinowski, M., Westdorp, I., Geise, H.J. J. Ors. Chem. 1982, 47, 248

Dams, R., Malinowski, M., Geise, H.J. Transition Mel. Chem. 1982, 7,37 .

(11) Hünig, S., Ort, B. Liebigs Ann. Chem. 1984, 1905

(12) Fürstner, A., Weidmann, H. Synthesis 1987, 1071.

(13) Marshall, J.A., Bierenbaum, R., Chung, K. H. Tetrahedron Lett. 1979, 2081

(14) Rieke, R. D. Top. Curr. Chem. 1975, 59, 1. Kahn, B.E., Rieke, R.D. Chom. Rev. 1988, 88, 733.

(15) Ghirenghelli, I). Tetrohedron Lett. 1983, 24, 287.

(15) Corey, E.J., Danheiser, Chandrasekaran. S. J. Org. Chem. 1976 $41,260$.

(17) Ishida, A., Mukaiyama, T. Chem. Lett. 1976, 1127.

(13) Brown-Wensley, K.A., Buchwald, S.L., Cannizzo, L., Clowson, L., Ho, S., Meinhardi, D., Stille, J. R.. Straus, D.. Grubbs, R.H Pure and Appl. Chem. 1983, 55, 1733.

(19) Sato, F. J. Organomet. Chem. 1985, 285, 53.

(20) McMurry, J.E., Lectka, T., Rico, J.G. J. Org. Chem. 1989, 54 , 3748 .

(21) Gapshi, G., Kini, A., Lin, R.S. H. Chem. Lett. 1978, 803

(22) Jung, M.E.. Lin, C.Y. J. Org. Chem. 1986, 51, 5446.

(23) Lenoir, D., Frank, R.M. Tetrahedron Lett. 1979, 505 Lenoir, D., Frank, R. M., Cordt, F., Gieren, A., Lamm, V. Chem. Ber. 1980, 113, 739

(24) Villasenor, R.S., Johrison, C. R. Org. Swnth. 1981, 60, 113.

(25) Olah, G.A., Prakash, G. K.S. Synthesis 1976, 607; Olah, G. A., Prakash, G. K.S., Liang, G. Synthesis 1976, 319

(26) Timberlake, J.W., Inn. Y.M. J. Org. Chem. 1979, 44, 4729.

(27) Wenek, H., de Meijerc, A., Gerson, F., Gleiter, R. Angew. Chem. Int. Ed. Engl. 1986, 25, 335.

(28) Langler, R. F., Tidwell, T. T. Tetrahedron Lett. 1975. 775

(29) Bomse, D.S., Morton. T. H. Tetrahedron Lett. 1975, 781

(31)) Olah, G.A., Prakash, G. K.S. I. Org. Chem. 1977. 42. 582.

(31) Lenoir, D. Chem. Ber. 1978, /11, 411.

(32) Gano, J.E., Lenoir, D., Park, B.S., Roesner, R. A. J. Org. Chom $1987,52$.

(33) Lenoir, D., Malwitz, D., Meyer, B. Tetrahedron 1.th. 1984, 25, 2965.

(34) Böhner. G., Knorr, R. Titrahedron Lett. 1984, 25, 3675

(35) Roth, W., Lenoir, D., unpublished results.

(35) Lenoir, D., Burghard, H. J. Chem. Res. (S), 1980, 396, (M), 4715

(37) McMurry, J.E. personal communication.

(38) Leimner, J., Weyerstahl, P. Chcm. Ber. 1982, 115, 3697.

(39) Lemmen. P. unpublished results.

(49) Bottino, F. A., Finocchiaro, P., Libertini, E., Reale, A., Reca, A. J. Chem. Soc., Perkin Trans. 2 1982, 77

(41) Gano, J.E., Lenoir, D., Park, B.-S., Pinkerton, A.A. to be published

Lenoir, D.. Gano, J.E.. McTague, J. Tetrahedron Lett. 1986, 27 , 5339 .

(42) Lenoir, D. unpublished results

(43) Newkome, G. R., Roper. J. M. J. Org. Chem. 1979, 44, 502.

(44) Willem, R., Pepermann, H., Halenga, K., Gielen, M.. Dams, R., Geise, H.J. J. Org. Chem. 1983, 48, 1980.

(45) Agranat, I., Suissa, M. R., Cohen, S., Isaksson, R., Sandstrom, J., Dale, J., Grace, D. J. Chem. Soc., Chem. Commun. 1987, 381.

(46) Lenoir, D., Lemmen, P. unpublished results. Lenoir, D., Lemmen, P. Chem. Ber. 1980, /13, 3112 Lemmen, P. Lenoir, ?. Chem. Ber. 1984, 117, 2300.

(47) Gano, J.E., Park, B.S., Pinkerton, A. A., Lenoir, D. J. Org. Chem., in press.

(48) McMurry, J. E., Krepski, L. R. J. Org. Chem. 1976, 4l, 3929.

(49) Doering, W.v.E., Roth, W. R., Bauer, F., Breuckmann, R. Ebbrecht, T., Herbolc., M., Lennartz, H.-W., Lenoir, D., Böse, R. Chem. Ber. 1989, 122,1263.

(50) Hopf, H., El-Tamany, S., Rauls, F.-W. Angew. Chem. Int. Ed. Engl. 1983, 22, 633.

(51) Reddy, S. M., Duraisamy, M., Walborsky, H.M. J. Org. Chem 1986, 51,2361

(52) Paquette, L.A., Yan, T.-H., Wells, G.J. J. Org. Chem. 1984, 49, 3610

(53) Coe, P. L., Criven, C. E. J. Chem. Soc, Perkin I 1986, 475.

(54) Beck. T.G., Barton. D.H.R., Britten-Kelley, M.R, Gusiec, F S Jr J Chem Soc purkin Trans / 1976, 19, 2079.
Buter, J., Wassenar, S., Kellogg, R. M. J. Org. Chom. 1972, 37, 4045 .

(55) Krubs, A., Rüger, W., Nickel, W.-U., Wilke, M., Burkert, U Chcm. Ber. 1984, 117, 310; and references cited therein.

(56) Cordt, F., Frank, R. M., Lenoir. D. Totrahedron Lett. 1979, 505.

(57) Krobs, A., Kaletta, B., Nickel, W.-U., Rüger, W., Tikwe, L. Tetrahedron 1986, 42, 1693.

(58) Roth. W. R., private communication. Herbold, M. Dissertation, University Bochum, 1989

(59) Gano, J.E., Wettach, R.H., Platz, M.S., Senthilnathan, V.P. $J$ Am. Chem. Soc. 1982, 104, 2336.

(60) Zimmerman, H. E., Dodd, J.R. J. Am. Chem. Soc. 1970, 92, 6507.

(61) Wong, C.S., Leung, W.S., Yeung, L. L... Luh, T.-Y. J. Organomet. Chem. 1986, 307, C 49.

(62) Abuscato, G. J., Tidwell, T. T. J. Am. Chem. Soc. 1975, 92. 4125. Tidwell, T. T. Tetrahedron 1978, 34, 1855.

(63) Lenoir, D., Danner, H., Frank, R. M. Chem. Bcr. 1980, /13, 3112 (64) Olah, G.A., Wu, A.-h. Farooq, O. J. Org. Chem. 1989. 54, 1375

(65) Dormagen, W., Breitmaier, F. Chem. Ber. 1986, 119, 1734

(66) Castedo, L., Saa, J M., Suan, R., Tojo, G. Tetrahedron Lett 1983. 24,5419

(67) Pattenden, G., Rohertson. G. M. Tetrahedron Lett. 1986, 27, 399

(68) Chen, T. L., Chan, T. I1., Shaver, A. J. Organometal. Chem. 1984, $26 \%, \mathrm{C} 1$

(69) Richardson, W.H. Syn. Commun. 1981, 11, 895

(70) Dans, R., Malinowski, M., Westdorp, I., Geise, H.J. J. Org Chem. 1981, 46, 2407

Dans, R., Malinowsky, M., Geise, H.J. Recl. Trav. Chim. PaysBas 1982, 101, 112 .

(71) Naxayama, J., Machida, H., Saito, R., Hoshino, M. Tetrahedron Lett. 1985, 26, 1981

(72) Na sayama, J., Ikuina, Y., Murai, F. Hoshino, M. J. Chem. Soc. Chem. Commun. 1987, 1072

(73) Seijas, J.A., deLera, A. R., Villaverde, M.C., C.stedo, L. J. Chem Soi. Chem. Commun. 1985, 839.

(74) Castedo, L., Sá́, J. M., Suau, R., Tojo, G. /. Olg. Chem. 1981, 46, 4292

(75) Handa, Y., Inanaga, J. Tetrahedron Lett. 1987, 28, 5717

(76) Betschart, C. Secbach, D. Helv. Chim. Acta 1987, 70, 2215

(77) McMurry, J.E., Miller, D. D. J. Am. Chem. So: 1983, 105, 1660.

(78) Baumstark, A. L., McCloskey, C.J., Witt, K. E. J. Org. Chem. $1978,43,3609$

(79) McMurry, J.E., Kees, K. L. I. Org. Chem. 1977, 42, 2655

(80) MeMurry, J.E., Swenson. R. Tetrahedron Lett. 1987, 28, 3209.

(81) Disanayaka, B. W., Weedon, A.C.J. Chem. Soc. Chem. Commun. 1985, 1282.

Disanayaka, B. W., Weedon, A.C. J. Org. Chert. 1987, 52, 2905

(82) McMurry, J.E., Bosch, G. K. Tetrahedron Lett. 1985, 26, 2167. McMurry, J. E., Bosch, G. K. J. Org. Chem. 1987, 52, 4885.

(83) Clive, D.L., Murthy, K.S.K., Wee, A.G.H., Prasad, J.S., da Silva, G.V.J., Majewski, M., Anderson, P.C., Hatugen, R.D. Heerze. L. D, f. Am. Chem. Soc. 1988, 110,69.4.

(84) Ben, I, Castedo, I., Saa, J.M., Seijas, J.A., Suau, R.. Tojo, G. J. Org. Chem. 1985, 50, 2236

(85) Keade, A.S., Johnson, S., Sanfilippo, P., Hodges, J.C.., Jungheim. L. N. J. Am. Chem. Soc. 1985, 108, 3513

(86) Begley, M.J., Pattenden, G., Robertson, G.M. J. Chem. Soc: Perkin / 1988, 1085

(87) Kato, N., Kataoka, H., Ohbuchi, S., Tanaka, S., Takeshita, H. J. Chem Soc. Chem. Commun. 1988, 364.

(88) Berlage, U., Schmidt, J., Peters, U., Welzel, P. Tetrahedron Lett. $1987,28,3091$.

(89) Ziegler, F. E., Lim, H. J. Org. Chem. 1982, 47, 5229

(90) Paquette, L.A., Dressel, J., Pansegrau, P. D. Tetrahedron Lett. 1987, $28,4965$.

(91) Vogel, E., Püttmann, W., Duchatsch, W., Schieb, T., Schmickler H., Lex, J. Angew. Chem. Inil. Ed. Engl. 1986, 25, 720.

(92) Vogel. E., Neumann, B., Klug, W., Schmickler, II., Lex, J. Angew Chem. Intl. Ed. Engl. 1985, 24, 1046.

(93) Tirado-Rives, J., Oliver, M.A., Fronzek, F. R., Gandour, R. D J. Org. Chem. 1984, 49,1627

(94) Marshall, J.A.. Flynn, K.E. J. Am. Chem. Soc. 1984, 106, 723 For a review of betweenancne synthesis, see Marshall, J.A. Ace Chem. Res. 1980, 13, 213

(95) Yamamoto, K., Harada. T., Nakazaki, M. J. Am. Chem. Soc $1983,105,7171$

Yamamoto, K., Harada, T., Okamoto, Y., Chikamatsu, H., Naka 
zaki, M., Kai, Y.. Nakao, T.. Tanaka, M., Harada, S. Kasai, N. J. Am. Chom. Soc. 1988, $110,3578$.

(96) Janssen, J., Lüttke, W. Chem. Ber. 1982, 115, 1234

(97) Kasahara, K., Izumi, T., Shimizu, I., Satou, M., Katou, T. Bull Chem. Soc. Jpn. 1982. 55, 2434.

(98) Shimizu, I., Umezawa, H., Kanno, T., Izumi, T., Kassahara, A Bull. Chem. Soc. Jpn. 1983, 56, 2023.

(99) Shimizu, I., Kamei, Y., Tezuka, T., Izumi. T., Kasahara. A. Bull Chem. Soc. Jpn. 1983, 56, 192, and references cited therein.

(100) McMurry, J.E., Haley, G.J., Matz, J.R., Clardy, J.C.. Van Duyne, G., Gleiter, R., Schäfer, W., White, D.H. J. Am. Chem. Soc. 1984, $106,5018$.

McMurry, J.E., Haley, G.J., Matz, J.R., Clardy. J.C., Van Duyne, G., Gleiter, R., Schäfer, W., White, D.H. J. Am. Chem. Soc. 1986, 108. 2932.

(101) McMurry, J. E., Haley, G.J., Matz, J. R., Clardy, J.C., Mitchell, J. J. Am. Chem. Soc. 1986, $108,515$.

(102) McMurry, J. E., Hodge, C.N. J. Am. Chem. Soc. 1984, 1016, 6450

(103) Vogcl, E., Sicken, M., Röhrig, P., Schmickler, H., Lex, J., Ermer. O. Angew. Chem. Intl. Ed. Engl. 1988, 27, 411.

(104) Vogel, E., Balci, M., Pramod, K., Koch, P., Lex, J., Ermer, O. Angew. Chem. Intl. Ed. Engl. 1987, 26, 928 and references therein

(105) Wu, Y.-J., Burnell, D.J. Tetrahedron Lett. 1988, 29. 4369.

(106) Jackson, C. B., Pattenden, G. Tetrahedron Lett. 1985. 26. 3393.

(107) McMurry, J.E., Kocovsky, P. Tetrahedron Lett. 1985, 26, 2171.

(108) McMurry, J. E., Matz, J. R. Tetrahedron Lett. 1982. 23. 2723.

(109) McMurry, J. E., Matz, J. R., Kees, K. L., Bock, P. A. Tetrahedron Lett. 1982, 23, 1777

McMurry, J.E., Matz, J.R., Kees, K.L. Tetrahedron. 1987, 43. 5489.

(110) McMurry, J. E., Rico, J.G., personal communication.

(111) Kato, N., Nakanishi, K.. Takeshita, H. Bull. Chem. Sor. Jpn. 1986, 59. 1109

(112) McMurry, J.E., Miller, D.D. Tetrahedron Lett. 1983, 24, 1885.
(11.3) Eaton, P.E., Johe, P. (i., Nyi, K. J. Am. Chom. So . 1980. I02, 6636.

(114) Dams, R., Malinowski, M., Geise, H.J. Red. Trar. Chim. Pa1s Bas 1980, 101, 112.

McMurry, J.E., Silvestri, M.G., Fleming, M.P., Hoz, T. Grayston. M.W. J. Org. Chem. 1978, 43, 3249.

(115) Schobert. R. Angew. Chem. Int. Ed. Engl. 1988. 27, 855.

(116) Riguerea, R., Quiñó E., Castedo, L. J. Chem. Soc. Chem. Commun. 1984, 1120.

(117) Walborski, H.M., Murari, M.P. J. Am. Chem. Soc. 1980. 10.2 . 426.

(118) Walborski, H.M., Wüst, H.H. J. Am. Chem. Soc. 1982, 104. 5807.

(119) Wong. H. N.C. Act. Chem. Res. 1989, 22, 145.

(120) Muraharshi, S. F., Kodera, Y. Tetrahedron Latt. 1985. 26. 4633.

(121) Tebbe. F.N., Pashall, G.W., Reddy, G.S. J. Am. Chom Soc 1978, 100,3611 .

(122) Anslyn, E.V., Grubbs, R.H. J. Am. Chem. Sic. 1987, I0\%, 4880

(123) Pine, R.H., Pettit, R.J.. Geib, C. D., Cruz, S.G., Gallego, C.H., Tijerina, T., Pine, R.D. J. Org. Chem. 1985, 50, 1212.

(124) Cannizo, L. F., Grubbs, R. H. J. Org. Chem. 1985, 50, 2316.

(125) Reißig, H.-U. Nachr. Chem. Techn. Lab. 1986, 34, 562.

(126) Stille, J.R., Grubbs, R.S. J. Am. Chem. Soc. 1986, 108.855.

(127) Buchwald, S. L., Grubbs, R.H. J. Am. Chm. Sor. 1983. 105 5490.

(128) Hibino, J.E., Okazoe, T., Takai, K.. Nozaki. H. Tetrahedron Lett. $1980,5579$.

(129) Okazoe, T., Takai, K., Oshima, K., Utimoto, K. J. Org. Chom. $1987,52,4410$

(130) Freudenberger. J.H., Konradi, A.W., Pedersen, S. F. .J. Am. Chem. Soc. 1989, IIl, 8014; and references cited therein.

(131) Léonhard, E., Duñach, E., Périchon, J. J. Chem. Sic. Chem. Commun. 1989, 276.

(132) Delair, P., Luche. J.-L. J. Chem. Soc.. Chom. Commun. 1989. 389. 